\title{
Similarities and differences of aerosol optical properties between southern and northern sides of the Himalayas
}

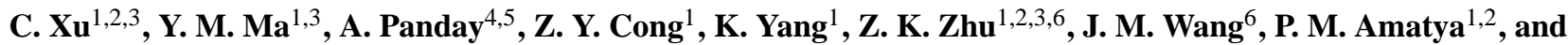 \\ L. Zhao ${ }^{1,2}$ \\ ${ }^{1}$ Key Laboratory of Tibetan Environment Changes and Land Surface Processes, Institute of Tibetan Plateau Research, CAS \\ Center for Excellence and Innovation in Tibetan Plateau Earth System Sciences, Chinese Academy of Sciences, \\ Beijing 100101, China \\ ${ }^{2}$ University of Chinese Academy of Sciences, Beijing 100049, China \\ ${ }^{3}$ Qomolangma Station for Atmospheric Environmental Observation and Research, Chinese Academy of Sciences, \\ Dingri 858200, Tibet, China \\ ${ }^{4}$ Department of Environmental Sciences, University of Virginia, Charlottesville, Virginia, USA \\ ${ }^{5}$ International Centre for Integrated Mountain Development (ICIMOD), Kathmandu, Nepal \\ ${ }^{6}$ Cold and Arid Regions Environmental and Engineering Research Institute, Chinese Academy of Sciences, \\ Lanzhou 730000, China
}

Correspondence to: Y. M. Ma (ymma@itpcas.ac.cn)

Received: 27 May 2013 - Published in Atmos. Chem. Phys. Discuss.: 13 August 2013

Revised: 14 February 2014 - Accepted: 17 February 2014 - Published: 31 March 2014

\begin{abstract}
The Himalaya mountains along the southern edge of the Tibetan Plateau act as a natural barrier for the transport of atmospheric aerosols from the polluted regions of South Asia to the main body of the Tibetan Plateau. In this study, we investigate the seasonal and diurnal variations of aerosol optical properties measured at two Aerosol Robotic Network (AERONET) sites on the southern side of the Himalaya (Pokhara, $812 \mathrm{~m}$ above sea level (a.s.l.) and EVK2CNR, 5079 ma.s.l. in Nepal) and one on the northern side (Qomolangma (Mt. Everest) station for Atmospheric and Environmental Observation and Research, Chinese Academy of Sciences (QOMS_CAS) in Tibet, $4076 \mathrm{~m}$ a.s.l. in China). While observations at QOMS_CAS and EVK2-CNR can generally be representative of a remote background atmosphere, Pokhara is a lower-elevation suburban site with much higher aerosol load due to both the influence of local anthropogenic activities and to its proximity to the Indo-Gangetic Plains. The annual mean aerosol optical depth (AOD) during the investigated period was 0.05 at QOMS_CAS, 0.04 at EVK2-CNR and 0.51 at Pokhara, respectively. Seasonal variations of aerosols are profoundly affected by large-scale atmospheric circulation. Vegetation fires, peaking during April in the Himalayan region and northern India, contribute
\end{abstract}

to a growing fine mode AOD at the three stations. Dust transported to these sites, wind erosion and hydrated/cloudprocessed aerosols lead to an increase in coarse mode AOD during the monsoon season at QOMS_CAS and EVK2CNR. Meanwhile, coarse mode AOD at EVK2-CNR is higher than at QOMS_CAS in August and September, indicating that the transport of coarse mode aerosols from the southern to the northern side may be effectively reduced. The effect of precipitation scavenging is clearly seen at Pokhara, which sees significantly reduced aerosol loads during the monsoon season. Unlike the seasonal variations, diurnal variations are mainly influenced by meso-scale systems and local topography. The diurnal pattern in precipitation appears to contribute to diurnal changes in AOD through the effect of precipitation scavenging. AOD exhibits diurnal patterns related to emissions in Pokhara, while it does not at the other two high-altitude sites. At EVK2-CNR, the daytime airflow carries aerosols up from lower-altitude polluted regions, leading to increasing AOD, while the other two stations are less influenced by valley winds. Surface heating influences the local convection, which further controls the vertical aerosol exchange and the diffusion rate of pollution to the surrounding areas. Fine and coarse mode particles 
are mixed together on the southern side of the Himalaya in spring, which may lead to the greater inter-annual difference in diurnal cycles of Ångström exponent (AE) at EVK2-CNR than that at QOMS_CAS.

\section{Introduction}

Studying tropospheric aerosols and their effects is important (Li et al., 2011). Atmospheric aerosols are among the largest sources of uncertainty in our ability to predict climate change, due to our inadequate understanding of aerosol properties and interactions (IPCC, 2007). This is particularly true for anthropogenic aerosols (Kaufman et al., 2002). On the one hand, aerosols absorbing and scattering solar radiation can change the atmosphere's temperature profile, the amount of solar radiation reaching the surface, as well as the reflected solar radiation at the top of atmosphere (Wild, 2009; Sena et al., 2013). On the other hand, aerosols can also act as cloud condensation nuclei (CCN), impacting cloud cover, cloud properties and precipitation, ultimately influencing the hydrological cycle (Ramanathan et al., 2001).

The Tibetan Plateau (TP) is the largest and highest plateau on earth. The TP usually acts as a receptor of natural and anthropogenic aerosols from the surrounding regions, and its environment is highly sensitive to climate change and human activities. The Himalaya mountains located along the southern edge of the TP act as a natural barrier for the transport of atmospheric aerosols.

Although many studies have focused on environmental and climate change on the TP (Xu et al., 2009; Yang et al., 2011; Yao et al., 2012), particularly in the Himalayan region (Lau et al., 2006; Gautam et al., 2009), knowledge about aerosol optical properties on the TP is limited. Although the TP often has pristine atmospheric conditions (Cong et al., 2009), both anthropogenic and natural aerosols have been found to be transported there (Cong et al., 2007). Some extreme pollution events recorded over the central TP suggest that pollution extending to $3-5 \mathrm{~km}$ above sea level (a.s.l.) was transported to the TP by prevailing southwesterly winds (Xia et al., 2011). Dust also influences the TP greatly, and airborne dust over the TP appears to be mainly associated with surrounding source regions, for example, the Taklimakan desert (Xia et al., 2008), the Tarim Basin, the Gobi Desert, as well as northwestern India and the Middle East (Huang et al., 2007; Liu et al., 2008). Dumka et al. (2011) have found the concentration of aerosols over the Himalayan region to decrease rapidly with altitude, with the Ångström exponent (AE) remaining high in the well-mixed region but decreasing above. Black carbon (BC) reaching the Himalayas and the Tibetan Plateau (HTP) has increased in recent years, and South Asia and East Asia appear to be the two main source regions ( $\mathrm{Lu}$ et al., 2012). Over the Indian Himalayan foothills, high concentrations of $\mathrm{BC}$ were related to the boundary layer dynam- ics and to human activities in the adjoining valley (Pant et al., 2006). Although the high peaks of the Himalaya appear to block the transport of $\mathrm{BC}$ particles to the TP, the Yarlung Tsangpo River valley acts as a "leaking wall" to contaminate the southeast TP (Cao et al., 2011).

When investigating aerosol optical properties, it is important to look at both seasonal and diurnal variations of aerosols. The characteristic timescale of variation of AOD is about $3 \mathrm{~h}$ in remote regions, but can be less than $1 \mathrm{~h}$ near emission sources (Anderson et al., 2003). Daytime variations of total aerosol or carbonaceous aerosol have been investigated in many regions, such as in North and South America (Zhang et al., 2012b), South Asia (Singh et al., 2004; Pandithurai et al., 2007; Gautam et al., 2011), and China (Wang et al., 2004).

Remote-sensing retrieval of AOD has been applied over many regions ( $\mathrm{Li}$ et al., 2007; He et al., 2010; Breon et al., 2011), but uncertainty in remote sensing has been high over the TP due to its low aerosol load (Wang et al., 2007). Previous investigations based on ground observation have indicated that the annual mean AOD observed at different sites of TP was usually less than 0.15 (Cong et al., 2009; Che et al., 2011). The Himalayan mountain range is shown to be affected by the advection of pollution from surrounding regions and long-range transport aerosols (Bonasoni et al., 2008; Gobbi et al., 2010). This paper analyzes the seasonal characteristics of fine and coarse mode aerosols, respectively, between southern and northern sides of the Himalayas using AERONET data. Diurnal variations of aerosol optical properties at three stations are presented and potential causes of the variations are discussed. The data and methodology are described in Sect. 2. Spatial patterns of precipitation and wind fields in the region are presented in Sect. 3.1. Seasonal aerosol optical properties are analyzed in Sect. 3.2, and diurnal aerosol variations are discussed in Sect. 3.3. Conclusions and discussion are given in the Sect. 4.

\section{Data and methodology}

\subsection{Site descriptions}

Three AERONET sites (QOMS_CAS, EVK2-CNR and Pokhara) have been selected for this study. QOMS_CAS is located on the northern side of Himalayas, while the other two sites are on the southern side. Climatic conditions are different between the southern and northern slopes. Details about the three sites are provided in Table 1 . The date ranges in the table are the investigated periods used to calculate annual means, seasonal variations and diurnal variations. The topography and the observation environment are shown in Fig. 1 (The photographs were obtained from http://aeronet. gsfc.nasa.gov/cgi-bin/site_info).

QOMS_CAS in China (Table 1, Fig. 1) is located in a northeast/southwest-oriented valley north of Mt. Everest. 
Table 1. The basic information of all three AERONET sites (QOMS_CAS, EVK2-CNR and Pokhara) includes longitude, latitude, elevation, and date ranges of the level 2.0 data.

\begin{tabular}{lcrrl}
\hline $\begin{array}{l}\text { Site } \\
\text { name }\end{array}$ & Longitude & Latitude & $\begin{array}{r}\text { Elevation } \\
(\mathrm{m}) \text { a.s.1. }\end{array}$ & $\begin{array}{l}\text { Level 2.0 } \\
\text { date range }\end{array}$ \\
\hline QOMS_CAS & $86.95^{\circ} \mathrm{E}$ & $28.37^{\circ} \mathrm{N}$ & 4276 & Oct 2010 to Dec 2012 \\
EVK2-CNR & $86.81^{\circ} \mathrm{E}$ & $27.96^{\circ} \mathrm{N}$ & 5079 & Mar 2006 to May 2011 \\
Pokhara & $83.97^{\circ} \mathrm{E}$ & $28.15^{\circ} \mathrm{N}$ & 812 & Jan 2010 to Dec 2012 \\
\hline
\end{tabular}

Notes: direct sun products and Spectral Deconvolution Algorithm (SDA) retrievals are used within the same date ranges at QOMS_CAS and Pokhara, while they are used within the different date ranges at EVK2-CNR. SDA retrievals began in May 2007 at EVK2-CNR.
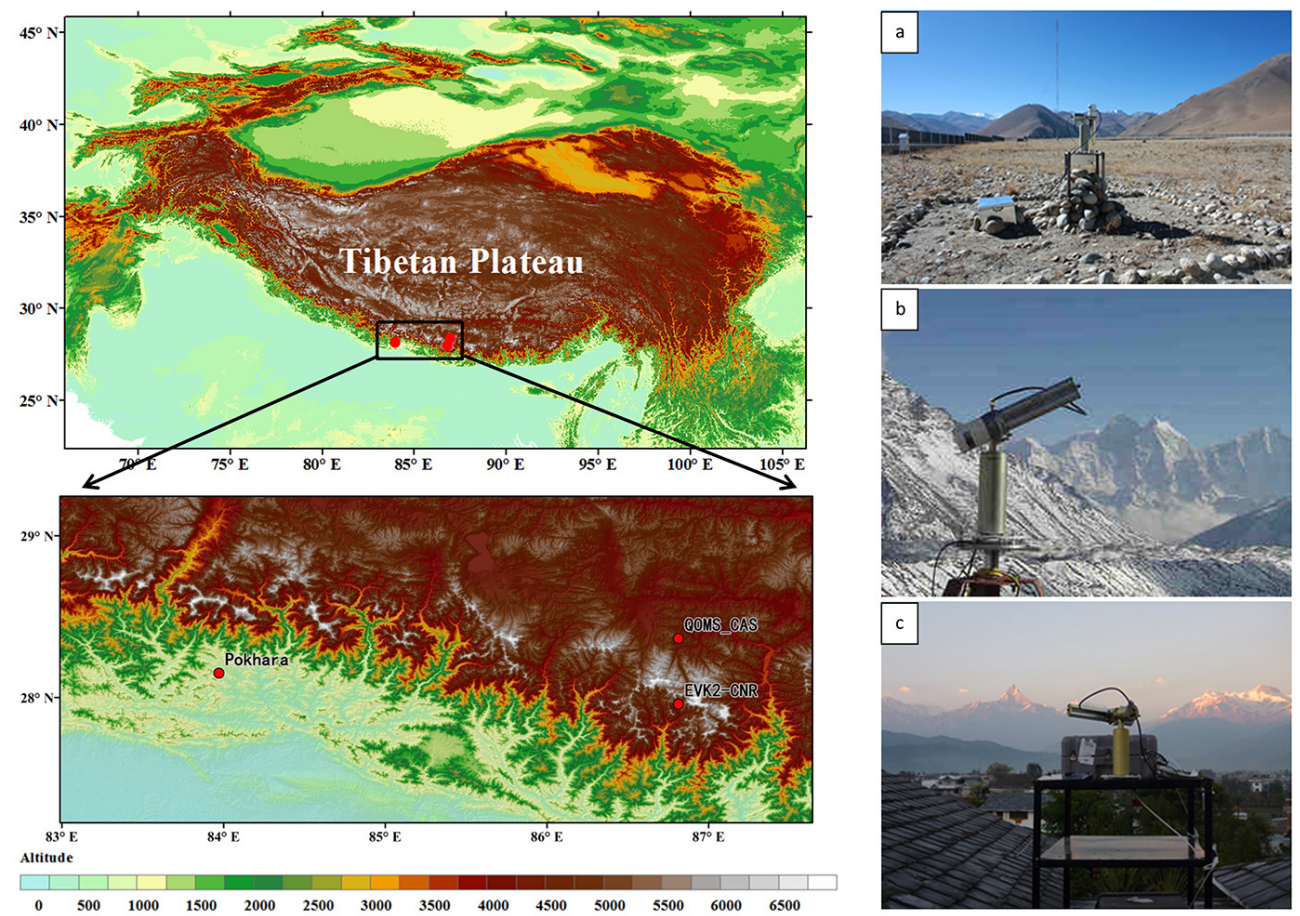

Fig. 1. The left pictures display the topography (in meters) map over the Tibetan Plateau and the locations of the three AERONET sites selected for this study. The right pictures show the AERONET sun photometer deployments in the field observations (a) QOMS_CAS, (b) EVK2-CNR, and (c) Pokhara.

Southwesterly winds near the surface prevail during the monsoon season, while in other seasons northeasterly winds prevail (Ma et al., 2011; Li et al., 2012). EVK2-CNR station in Nepal (Table 1, Fig. 1) is located in a valley to the southwest of Mt. Everest. The surrounding area is dominated by large moraines and high mountains (5800-6200 m a.s.1.). The wind regime is characterized by evident mountain-valley circulation. The dominant surface wind direction is from the south during the daytime all year long. Outside of the monsoon season, mountain winds prevail during nighttime and northwesterly winds are observed due to the effect of the westerly winds (Bonasoni et al., 2008, 2010; Gobbi et al., 2010). QOMS_CAS and EVK2-CNR are very near each other, with a linear distance between the two stations of $47.9 \mathrm{~km}$ on Google Earth. The third site, Pokhara, Nepal (Table 1, Fig. 1) is a suburban site at the southern end of Pokhara City, on the roof the Shangri-La Village Resort. As a result of the sharp elevation gradient to its north, Pokhara has one of the highest precipitation rates in Nepal. Summer is humid and mild, with most rainfall occurring during the monsoon season (JulySeptember). Winter and spring skies are generally clear and sunny (Kansakar et al., 2004), although increasingly affected by haze penetrating from the Indo-Gangetic plains.

\subsection{AERONET data}

AERONET is a federated international ground-based global network established for characterizing aerosol optical properties and validating aerosol satellite retrievals. This network has more than 450 stations operational globally, using 
a unified data correction method to ensure data quality (Holben et al., 1998). Previous researchers have used the AERONET network to study physical properties of ocean, desert dust, biomass burning and urban aerosol (Dubovik et al., 2002a; Smirnov et al., 2002b). The CIMEL sun photometers deployed at each AERONET site measure aerosol optical properties using two observation modes. First, the instrument measures the direct solar irradiances in wavelength channels $340 \mathrm{~nm}, 380 \mathrm{~nm}, 440 \mathrm{~nm}, 500 \mathrm{~nm}, 675 \mathrm{~nm}$, $870 \mathrm{~nm}, 1020 \mathrm{~nm}$ and $1640 \mathrm{~nm}$ to acquire the aerosol optical depth, while using a spectral channel at $940 \mathrm{~nm}$ to obtain water vapor content. Second, the instrument spins around, making sky diffuse radiation measurements at four spectral channels $(440 \mathrm{~nm}, 675 \mathrm{~nm}, 870 \mathrm{~nm}$ and $1020 \mathrm{~nm}$ ) to acquire aerosol microphysical and optical properties (Holben et al., 1998, 2001). Parameters such as aerosol size distribution, single-scattering albedos, asymmetry factor and refractive index are obtained using inversion algorithms (Dubovik and King, 2000; Dubovik et al., 2002b). The uncertainty in AOD for Level 2 AERONET data is 0.01 to 0.02 (Eck et al., 1999). The wavelength $(\lambda)$ dependence of AOD is characterized by the Ångström exponent (AE) using the classical empirical equation $\operatorname{AOD}(\lambda)=\beta \lambda^{-\mathrm{AE}}$, where $\beta$ is the turbidity coefficient (Ångström, 1929, 1964). The equation $\Delta \mathrm{AE}=\left[\frac{\sum_{i=1}^{n} e_{i}^{2}}{(n-2) \sum_{i=1}^{n}\left(\ln \lambda_{i}-\overline{\ln \lambda}\right)^{2}}\right]^{\frac{1}{2}}$ can be used to estimate the uncertainty in $\mathrm{AE}$, where $e_{i}$ is the error of the Angström relation, $n$ is the number of wavelengths $\lambda_{i}$ used to fit the Angström relation, and $\overline{\ln \lambda}$ is the average logarithm of the wavelengths (Kato et al., 2000). The ratio $\frac{\varepsilon_{i}}{\mathrm{AOD}_{i}}$ can be used to represent $e_{i}$, and the uncertainty in AOD of 0.01 for $\varepsilon_{i}$ recommended by Kato et al. (2000) is used. The equation, accounting for different kinds of errors in AOD, can help us obtain the usual maximum error for $\mathrm{AE}$. In each measurement, the uncertainty in AE 440-870 nm can be estimated using 870, 675, 500 and $440 \mathrm{~nm}$ AOD data. Table 2 shows the monthly median uncertainties in AE. Uncertainties in AE at QOMS_CAS and EVK2-CNR are higher than those at Pokhara, because uncertainties in AE increase dramatically when AOD is as low as measurement uncertainty. Therefore, there are large uncertainties in $\mathrm{AE}$ with quite low AOD observations. In addition, contamination by undetected clouds and hygroscopic growth of aerosol particles may lead to a decrease in $\mathrm{AE}$ and an increase in AOD in the humid environment surrounding clouds (Chand et al., 2012). At present, AERONET data are available as level 1.0, level 1.5 and level 2.0 data products, denoting raw data, automatically cloud-cleared data, and manually inspected data, respectively. Cloud-screening and quality control algorithms ensure the quality of level 2.0 AERONET data (Smirnov et al., 2000). Therefore, only the level 2.0 AERONET data are used in this study.
Table 2. The monthly median uncertainties in Angström exponent 440-870 nm at QOMS_CAS, EVK2-CNR and Pokhara.

\begin{tabular}{cccc}
\hline Month & QOMS_CAS & EVK2-CNR & Pokhara \\
\hline 1 & 0.95 & 1.29 & 0.11 \\
2 & 1.01 & 1.24 & 0.09 \\
3 & 0.59 & 0.87 & 0.07 \\
4 & 0.66 & 0.83 & 0.05 \\
5 & 0.52 & 0.87 & 0.07 \\
6 & 0.69 & 0.65 & 0.09 \\
7 & 0.45 & 0.56 & 0.23 \\
8 & 0.71 & 0.35 & 0.37 \\
9 & 0.82 & 0.52 & 0.36 \\
10 & 0.83 & 0.93 & 0.14 \\
11 & 1.31 & 1.47 & 0.15 \\
12 & 1.17 & 1.43 & 0.14 \\
\hline
\end{tabular}

\subsection{Satellite data and reanalysis data}

In this study, level 3 TRMM precipitation products, 3B43 version 7 and 3B42 version 7, are used to investigate rainfall spatial features and daytime variations. Temporal resolution of 3B43 data is one month, and its spatial resolution is $0.25^{\circ} \times 0.25^{\circ}$. The temporal resolution of $3 \mathrm{~B} 42$ data is 3 hours, with the same spatial resolution of $0.25^{\circ} \times 0.25^{\circ}$ (Huffman et al., 2007). TRMM 3B43 data of 2010 and 2011 are used to obtain spatial features. To obtain monthly precipitation, we have multiplied the hourly rain rate with the total hours in that month using $3 \mathrm{~B} 43$ product. The total precipitation in a season is calculated by summing the monthly precipitation in that season. To reflect the actual rainfall during the observation periods, we average the accumulated precipitation of 2010 and 2011 in each season. Four common seasons are used in this study. 3B42 data are used to obtain rainfall daytime variations. TRMM data are used to analyze diurnal rainfall changes rather than station observations. Compared with station data, TRMM data have the same observation mode, same data processing and better continuity at these three stations. We extract the values from the grids where these stations are located to obtain time series of precipitation. Using the extracted values at different times of day, we obtain the diurnal variations of precipitation rate (PR) across all seasons. For diurnal variations, the date ranges of TRMM 3B42 data are selected to match with AERONET data at each station.

Wind fields at $850 \mathrm{hPa}$ are examined using ERA-interim monthly mean reanalysis data. This reanalysis data are the products of the European Centre for Medium-Range Weather Forecasts (ECMWF). The spatial resolution of ERA-interim reanalysis data is $0.75^{\circ} \times 0.75^{\circ}$. Wind field data are used for the years 2010 and 2011. The seasonal mean of wind fields is calculated by averaging the monthly means in each season. NCEP/NCAR reanalysis data $\left(2.5^{\circ} \times 2.5^{\circ}, 6 \mathrm{~h}\right.$ temporal resolution) are used for back-trajectory calculations. The 5-day 
air mass backward trajectories are calculated using the Hybrid Single-Particle Lagrangian Integrated Trajectory (HYSPLIT) model version 4.9. Back trajectories are run every $6 \mathrm{~h}$ for April and July in 2012. The arrival height is set at $1 \mathrm{~km}$ above ground level (a.g.l.).

\subsection{Analysis methods}

Aerosol optical properties throughout the year are shown using total AOD at $500 \mathrm{~nm}$, fine mode AOD at $500 \mathrm{~nm}$ and $\mathrm{AE}$ at $440-870 \mathrm{~nm}$. Total AOD and fine mode AOD data are based on the Spectral Deconvolution Algorithm (SDA) retrievals (O'Neill et al., 2003). Total AOD reflects the extinction by both coarse and fine mode aerosols, while fine mode AOD reflects only the extinction by fine mode aerosols. Some unreliable measurements needed to be eliminated before analysis. Only data falling within the ranges $0.01<$ total $\mathrm{AOD}<3,0<$ fine mode $\mathrm{AOD}<3$ and $0<\mathrm{AE}<3$ at the same time are considered (direct sun products of AOD and AE use the same ranges). In Figs. 3, 4 and 6 box and whisker plots are used to show the aerosol properties. The median, rather than the mean, is used to represent the seasonal characteristics, because the mean is greatly affected by some extreme events. If the median is lower than the mean, the parameters of aerosols have high values in extreme events. Fine mode fraction (FMF) at $500 \mathrm{~nm}$ is defined as the ratio of fine mode AOD to total AOD. In this study, the monthly FMF is calculated by dividing the monthly median of fine mode AOD by the monthly median of total AOD in each month. FMF can be used to analyze the seasonal variations of particle size and deduce the major aerosol type (He et al., 2012a).

The single scattering albedo (SSA) provides information about the extent to which an aerosol is absorbing or scattering. Some studies have successfully combined SSA with other parameters to determine the aerosol type over different regions (Lee et al., 2010; He et al., 2012b; Logan et al., 2013). However, over regions with low aerosol load (AOD $440 \mathrm{~nm}<0.40$ ) it is difficult to obtain aerosol type by SSA due to inadequate accuracy (Dubovik and King, 2000). A graphical method applied to classify aerosols (Gobbi et al., 2007) is also not suitable for the higher altitude sites in our study because it needs AOD $>0.15$ to have sufficient accuracy.

The direct sun products of AOD and AE are used in our examination of diurnal variations. The direct sun products of AOD data have a much longer time series because total AOD and fine mode AOD are calculated by SDA. Thus the diurnal variations of total AOD and fine mode AOD are not calculated due to sparse data and poor continuity. The reason for using AE instead of FMF to evaluate the daytime variations of aerosol size is the same as above. However, some unreliable measurements need to be eliminated too. All hourly average observations in a day are expressed as a departure percentage from the daily mean (Smirnov et al., 2002a). Because there is no unified classification stan- dard for the monsoon season over this region, we don't analyze diurnal variations of AOD and AE in this study using a division of monsoon season and non-monsoon season. Also, the South Asian monsoon influences the study region at different times in each year. Although the three stations are not far apart, they have different onset and departure dates of the South Asian monsoon. We have thus divided the data into four common seasons, namely, March to May (MAM), June to August (JJA), September to November (SON) and December to February in the next year (DJF). This also allows better comparison with previous studies in other regions. In each period, we have converted the UTC time in the data files to local time (LT) and computed the hourly mean of AOD and $\mathrm{AE}$, for example, between 10:00 and 11:00 local time in each day. Due to the large change in time zone across the border (Nepal is UTC +5.75 , China is UTC +8 ) we have used an approximate LT of UTC +6 for all three stations. If the available hourly means on any particular day covered less than five hours, then that day would be excluded. The percentages and the absolute departures of each hourly average from the daily mean were calculated. The diurnal variations in each season were calculated by aggregating hourly departures for each local hour for the season. If the hourly average in a particular season had less than 10 days of available data then that hourly average in that particular season was excluded, since there would have been too few observations to represent the diurnal patterns in that season. A multiyear diurnal variation for each season is obtained by averaging across multiple years. The diurnal variations of PR are calculated by the same method using TRMM data.

\section{Results}

\subsection{Meteorological feature}

Regional meteorology is one of the key factors influencing aerosol optical properties. Figure 2 shows the seasonal variations of precipitation and prevailing winds at $850 \mathrm{hPa}$. In the Himalayan region precipitation is highest in summer, followed by spring. It is lowest in winter. Towards the end of MAM, the South Asian monsoon begins to develop and southwesterly winds blow towards the southeast TP. Precipitation is less than $100 \mathrm{~mm}$ across nearly the whole TP during this period. The southeast TP is wetter than other parts of the TP. In JJA, southwesterly, southeasterly and southerly winds prevail in the Himalayan region and northern India. Winds bring much moisture and rainfall increases significantly. Precipitation is heavier over the southern part of the TP than over the northern part. The Himalayas play an important role in blocking moisture transported to the main body of the TP. Along much of the southern side of the Himalayas, precipitation exceeds $1200 \mathrm{~mm}$. Rainfall decreases significantly in SON with the retreat of monsoon. Southerly winds prevail only in the northeast of India in autumn. During winter, the 
regional dominant wind direction is from the northwest, and precipitation is less than $100 \mathrm{~mm}$ over most regions of the TP.

In short, mechanical forcing and unique elevated thermal forcing have a large impact on regional as well as global climate. The mechanical and thermal forcing by the TP is responsible for the relative contributions of the climbing and deflecting effects of mountains (Wu et al., 2012). This mechanism greatly influences the transport of air pollutants and moisture (Wu et al., 2007; Cao et al., 2011). The Himalayas act as a natural barrier because of both the mechanical and thermal forcing effects of the TP. Therefore, the southern side of the Himalayas and northern India has much more precipitation than the TP, especially during summer and autumn.

\subsection{Seasonal variations}

The annual mean AOD during the investigated period was 0.05 at QOMS_CAS, 0.04 at EVK2-CNR and 0.51 at Pokhara, respectively. Pokhara is a suburban site with much higher annual mean aerosol load. Monthly statistics of aerosol properties are presented in Figs. 3, 4, 6 and 7. Seasonal characteristics differ among the stations.

Total AOD (Fig. 3) is quite low at QOMS_CAS and EVK2-CNR, but much higher at Pokhara. There may be a local contribution from Pokhara City (with population of 200000 ), but Pokhara is also in a region of Nepal with significant rural biomass burning, and downwind of the IndoGangetic Plains, which are often covered in haze during winter and spring (Ramanathan and Ramana, 2005). At QOMS_CAS, the maximum monthly mean of 0.08 occurs in July, and the maximum monthly median of 0.08 also occurs in July. All monthly means are higher than monthly medians, indicating contributions by short events with high aerosol loads. Both monthly mean and median are less than 0.10, suggesting pristine atmospheric conditions at QOMS_CAS. The lowest aerosol load is recorded in November and December. Total AOD at EVK2-CNR shows a similar pattern to that at QOMS_CAS. Here too, most monthly means are higher than monthly medians, except in August and September. The maximum monthly mean of 0.06 occurs in April, and the maximum monthly median of 0.06 occurs in August. The monthly mean and median in August and September at EVK2-CNR are higher than that at QOMS_CAS, illustrating that the transport of aerosols from the southern to the northern side of the Himalaya is effectively reduced. It is not clear from our data whether this is due to physical blocking by the mountains, or due to scavenging by rain of aerosols on the southern side of the Himalaya before they are able to cross over. Both monthly mean and median are less than 0.04 from October to February at EVK2-CNR. At Pokhara, meanwhile, total AOD shows two peak values per year, unlike at QOMS_CAS and EVK2-CNR. The monthly mean and median have similar seasonal patterns, but the peak months are different. The peak values of monthly means occur in April and November, while the peak values of monthly medians are in April and October. For both monthly means and monthly medians, the April peak is higher. April is a time of both frequent forest fires on the southern side of the Himalaya and a time when haze from the Indo-Gangetic Plains penetrates deep into the Nepal Himalayas. All monthly means at Pokhara are higher than monthly medians, especially in November. The aerosol loads are lower from July to September than in other months, as a result of heavy rainfall during the monsoon season.

The seasonal variations of fine mode AOD (Fig. 4) are different from total AOD at QOMS_CAS and EVK2-CNR. The maximum monthly mean and median are in April at QOMS_CAS. Previous studies showed that March to June was a major fire season in the low-altitude areas in the Himalayan region, and vegetation fires peaked in April (Vadrevu et al., 2012). Smoke aerosols released during big, strong forest fires in northern India and in the Himalayas can be transported above the planetary boundary layer by deep convection (Vadrevu et al., 2008; Tosca et al., 2011), and can be further transported to the central TP by atmospheric circulations (Xia et al., 2011). At EVK2-CNR, the maximum monthly mean and median are in April too. The aerosol loads are a bit higher from March to June and in August than other months. Pokhara, in contrast to the other two sites, shows a seasonal distribution of fine mode AOD that is similar to total AOD. The maximum monthly mean and median occur in April, and lower values are recorded from July to September. The monthly mean of fine mode AOD is almost two times higher than the median in November, due to some extremely high aerosol load events. For instance, on 3 November 2011, total AOD is 2.50 and fine mode AOD is 2.46. These extreme events may be influenced by agriculture crop residue burning over the Indo-Gangetic Basin during October and November (Mishra and Shibata, 2012).

HYSPLIT back trajectories were used to identify possible source regions and to explore the influence of long-range transport of smoke and dust aerosols to our study region. NCEP/NCAR monthly reanalysis data $\left(2.5^{\circ} \times 2.5^{\circ}, 6 \mathrm{~h}\right.$ temporal resolution) were input to HYSPLIT model. Figure 5 shows examples from April and July 2012. Due to the relatively close locations and similar aerosol sources, only the frequency plots for 5-day back trajectories arriving $1 \mathrm{~km}$ a.g.l. at QOMS_CAS are shown. In April, most of the air masses appear to come from the west, agreeing well with the prevailing westerly winds. The Himalayas and northern India are seen as the major source regions. Vegetation fires in the Himalayan region and northern India appear to impact the environment in the Everest region significantly during this period, as at Pokhara. The frequency plot for July indicates that the South Asian monsoon may carry aerosols to the study sites. Airflows mainly come from two directions, which are in accord with two branches of South Asian monsoon. The airflow originating from the Arabian Sea may carry dust from northwestern India (e.g., Thar Desert) to the study sites. Thus dust may have a significant impact on these stations. This is 

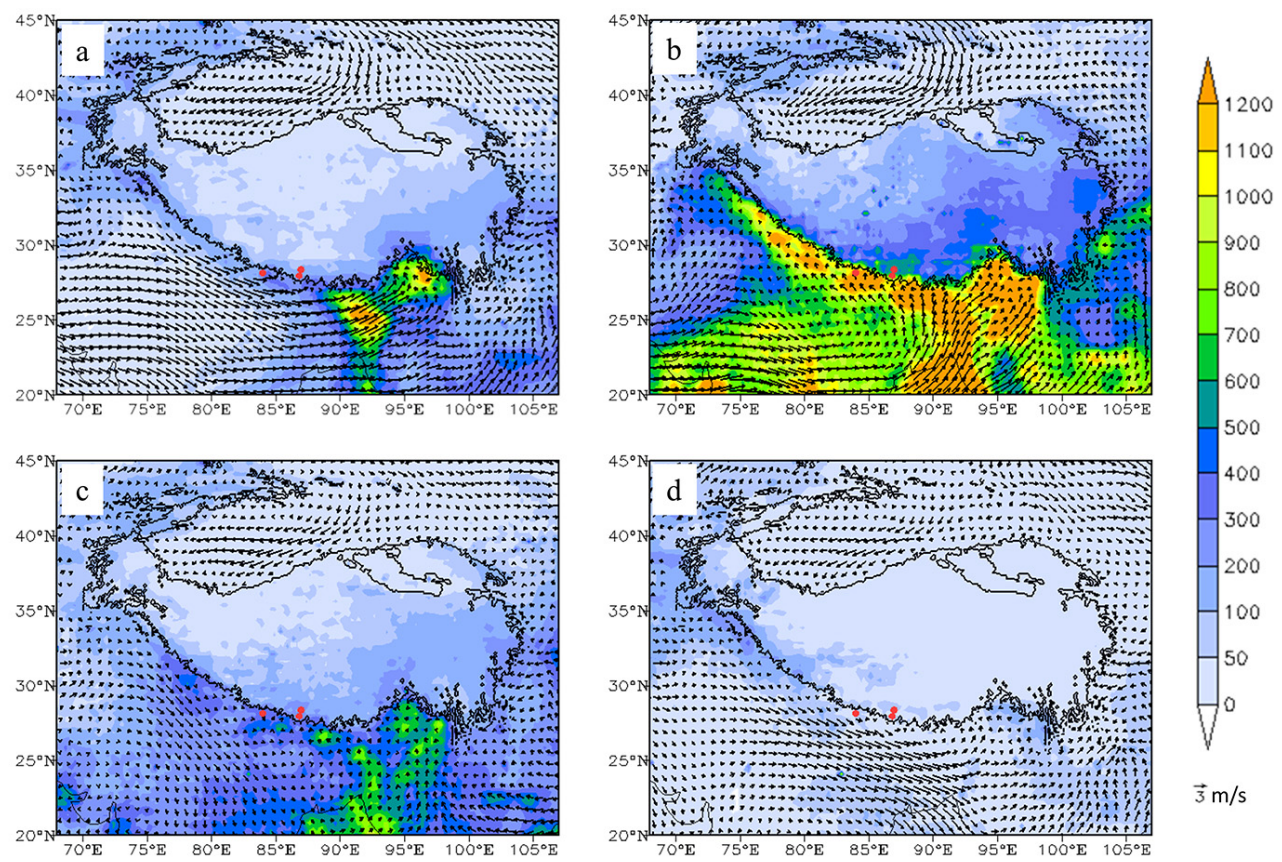

Fig. 2. Spatial distribution of TRMM-derived seasonal mean climatology of accumulated precipitation ( $\mathrm{mm}$ ) and wind at $850 \mathrm{hPa}$ over the Tibetan Plateau (a) March to May (MAM); (b) June to August (JJA); (c) September to November (SON); (d) December to February (DJF). The bold black line marks the geographic location of Tibetan Plateau, and the red dots indicate the locations of the three stations.

similar to the results of previous studies (Carrico et al., 2003). The results based on HYSPLIT back trajectories indicate potential aerosol source regions; however they are subject to the uncertainty and disadvantage of the HYSPLIT model (Koracin et al., 2011). The coarse resolution of the meteorological fields that drives HYSPLIT do not take into account thermally driven flows through Himalayan valleys and up slopes.

Figure 6 shows AE at the three sites. At QOMS_CAS, the maximum monthly mean and median occur in April. The monthly means are lower from August to October, while the monthly medians are lower from August to November. The figure suggests that fine particles may account for the majority of the aerosol concentration in April, but a minority during monsoon season. The seasonal pattern of AE at EVK2CNR is similar to that at QOMS_CAS from April to December. The maximum monthly mean and median AE occur in April. AE is slightly higher in April and in winter, while it is lower from July to September. At Pokhara, the highest value of AE occurs in September. All the monthly mean and median, more than 1.0, are much higher than at the other two stations. There are fewer available measurements from July to September due to heavy precipitation, and the available measurements in July are the fewest. High monthly mean and median of $\mathrm{AE}$ indicate that the majority of the aerosol concentration may consist of fine particles.

The fine mode fraction (FMF) (Fig. 7) can also reflect the particle size, and FMF is well correlated with $\mathrm{AE}$ at each site. However, there are still some differences between $\mathrm{AE}$ and FMF, because AE can be changed according to the effective radius of the fine mode aerosol and the ratio of fine mode to total volume concentration (Lee et al., 2010). At QOMS_CAS, the maximum FMF of 0.75 occurs in February. FMF is much higher in February and April $(>0.70)$ than in other months. FMF is lower from June to December. Aerosol compositions at QOMS_CAS appear to be dominated by fine particles in February and April. At EVK2-CNR, the maximum FMF of 0.76 occurs in April, and low values of FMF occur from July to September. FMF is less than 0.40 during these months, which is lower than at QOMS_CAS. This suggests that the majority of the aerosol concentration consists of coarse particles at EVK2-CNR, and suggests that there may be dust transported to the station or wind erosion taking place nearby even during the rainy summer months. At Pokhara, all FMF exceeds 0.60. Lower FMF occurs from March to June, and FMF in other months even exceeds 0.85 . The ratio of fine mode particles to total volume concentration may decrease from March to June, which indicates that dust also appears to occur during these months. Liu et al. (2008) also reported that large occurrence frequencies of dust were found on the southern side of Himalayas during spring. However, fine mode particles still account for the majority of the aerosol concentration throughout the year at Pokhara.

Figure 7 also shows monthly precipitation from TRMM at these sites. The three sites show similar seasonal pattern of precipitation. The maximum precipitation occurs in July at all sites. The average precipitation in July is $201 \mathrm{~mm}$ 

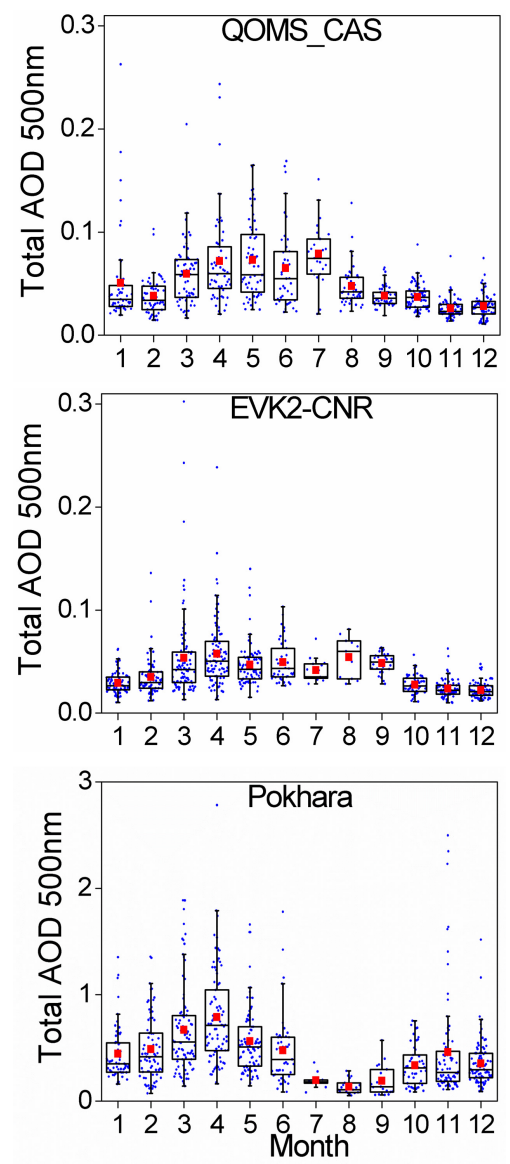

Fig. 3. Box plots of total aerosol optical depth at $500 \mathrm{~nm}$ at QOMS_CAS, EVK2-CNR and Pokhara. The blue dots represent daily observations. The central bar is the median, and the box shows the first and the third quartiles, respectively. The whisker shows the lower and upper extreme values. The solid red block symbols indicate arithmetical means.

at QOMS_CAS, $288 \mathrm{~mm}$ at EVK2-CNR and $519 \mathrm{~mm}$ at Pokhara, respectively. From April to September, the monthly precipitation is highest at Pokhara, and followed by at EVK2CNR. Conversely, precipitation at Pokhara is lower than the other two sites from October to March. The monthly precipitation is less than $60 \mathrm{~mm}$ at the three sites during these months. The inter-annual difference in precipitation is usually higher from April to September than other months at the three sites.

In summary, QOMS_CAS and EVK2-CNR do have relatively pristine environments occasionally disturbed by pollution episodes. Pokhara, however, is seriously affected by human activities. Both total AOD and fine mode AOD at Pokhara are much higher than the other two sites in each month. Vegetation fires peak in the Himalayan region in April (Vadrevu et al., 2012), which has a large impact on all three sites.
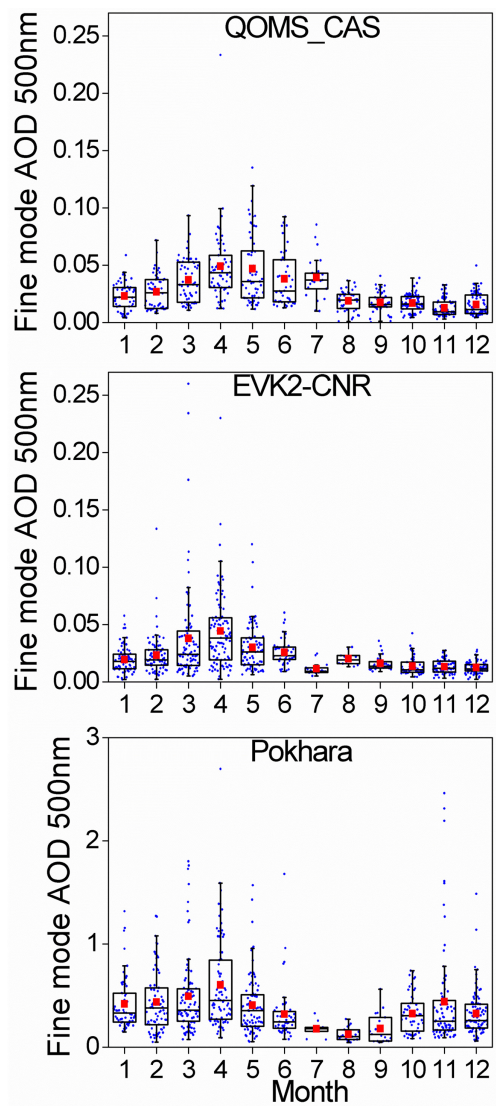

Fig. 4. Box plots of fine mode aerosol optical depth at $500 \mathrm{~nm}$ at QOMS_CAS, EVK2-CNR and Pokhara. Same symbols are used as in Fig. 3.

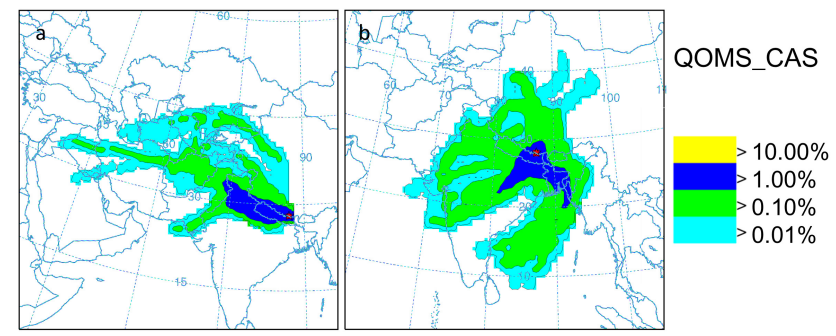

Fig. 5. Color-coded frequency plots of 5-day back trajectories by using HYSPLIT at QOMS_CAS (a) April 2012; and (b) July 2012. The red star indicates the location of QOMS_CAS site. To reflect the frequency plots clearly, different domains are used for the left and right panel.

It is possible that during monsoon season, higher total AOD at QOMS_CAS and EVK2-CNR may be partly caused by cloud contamination, as low $\mathrm{AE}$ and high precipitation occur during this period. However, higher total AOD during monsoon season may also be a natural phenomenon: dust transported to these sites or wind erosion taking place nearby can be seen during monsoon season. Direct sampling observations over northeastern Himalayas have found 

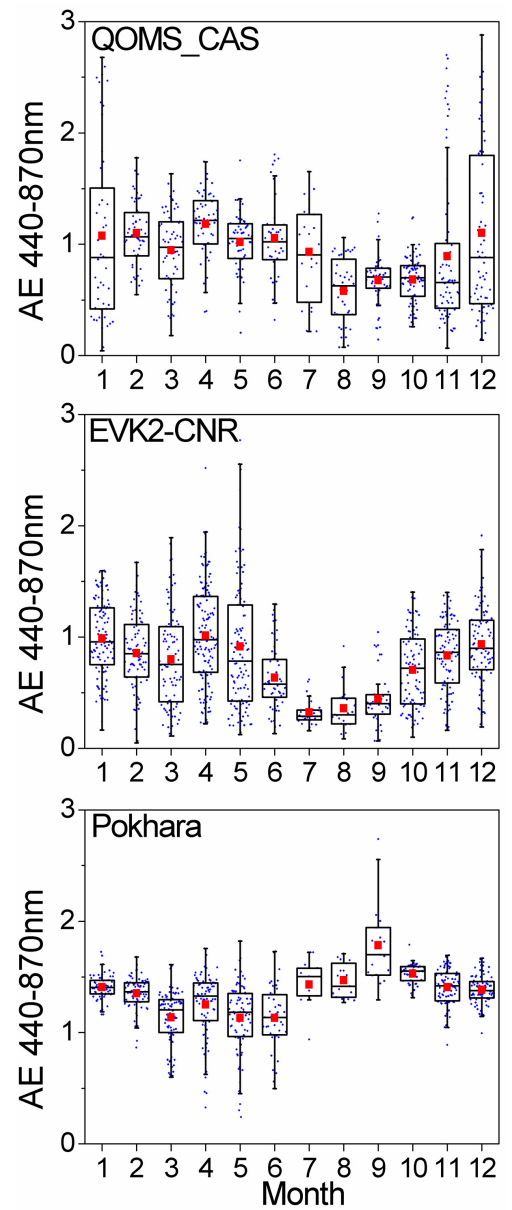

Fig. 6. Box plots of Ångström exponent at $440-870 \mathrm{~nm}$ at QOMS_CAS, EVK2-CNR and Pokhara. The same symbols are used as in Fig. 3.

fine mode aerosol dominating during dry seasons and coarse mode aerosol dominating during monsoon (Chatterjee et al., 2010), which is consistent with the result of this study.

\subsection{Diurnal variations}

\subsubsection{Precipitation rate}

To interpret the possible effects of rains, the diurnal cycle of PR based on TRMM data is shown in Fig. 8. The diurnal variations of precipitation show a consistent pattern in each season across the years. The daytime variation is largest in the summer at all the sites, and the smallest in winter. The inter-annual fluctuation is largest in summer. PR at Pokhara is higher than at the two high-altitude stations, except in winter, and PR at EVK2-CNR is slightly higher than at QOMS_CAS. The PR peak at each site generally occurs in the late afternoon. This may be related to the strong interaction between meso-scale convective systems and steep terrain (Barros et al., 2000).
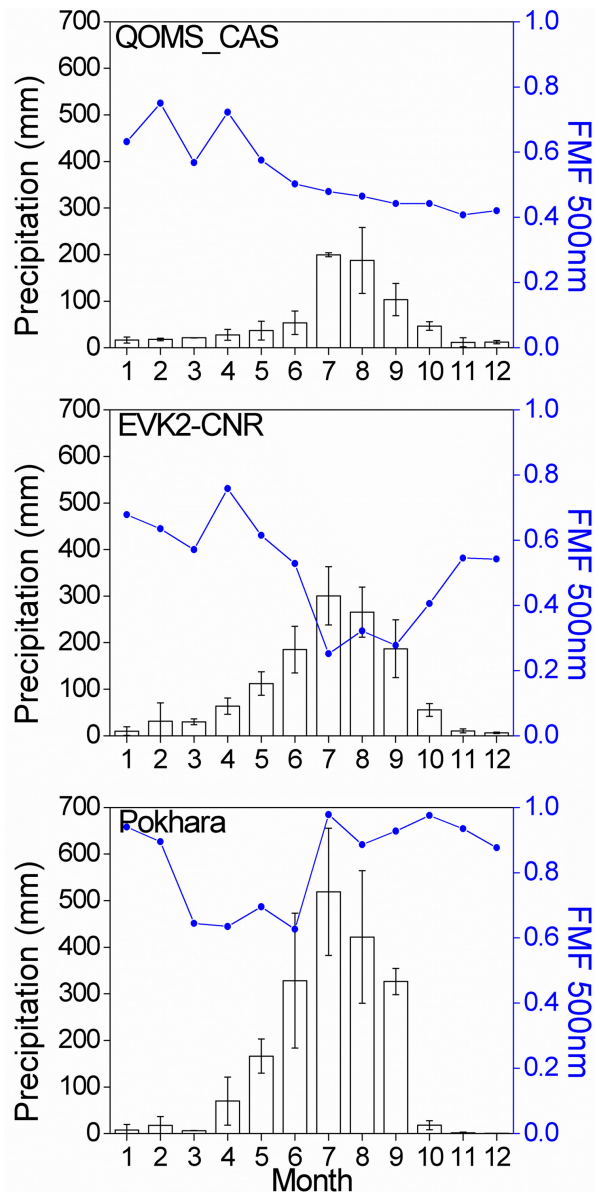

Fig. 7. Monthly means of accumulated precipitation ( $\mathrm{mm}$ ) and fine mode fraction (FMF). The error bars for precipitation indicate the inter-annual difference.

The diurnal variations of PR do not show similar patterns in each season at QOMS_CAS. PR is less than $0.1 \mathrm{~mm} \mathrm{~h}^{-1}$ during the day in MAM. Rainfall mainly occurs in the afternoon in JJA. The lowest PR in summer is close to zero at 09:00 (LT, the time below is LT without a specific instruction). PR rises sharply from 12:00 to 18:00, reaches a maximum at 18:00, and then fluctuates until midnight. The peak value of PR is observed in SON and DJF but the occurrence time is different.

PR is higher at EVK2-CNR than at QOMS_CAS except in winter. PR in spring (MAM) and autumn (SON) is less than $0.2 \mathrm{~mm} \mathrm{~h}^{-1}$, but in winter (DJF) is less than $0.1 \mathrm{~mm} \mathrm{~h}^{-1}$. It rains more in the late afternoon and at night rather than in the morning in each season. In JJA, PR decreases from 03:00 to $06: 00$, and then increases slowly from 06:00 to $15: 00$. PR increases dramatically from 15:00 to 18:00, reaches a maximum at 18:00, and then decreases sharply.

Daytime variations of PR in each season at Pokhara are clearly different from the two high-altitude stations. Pokhara has the highest precipitation among these three stations except in winter. In MAM, a higher PR value (about 

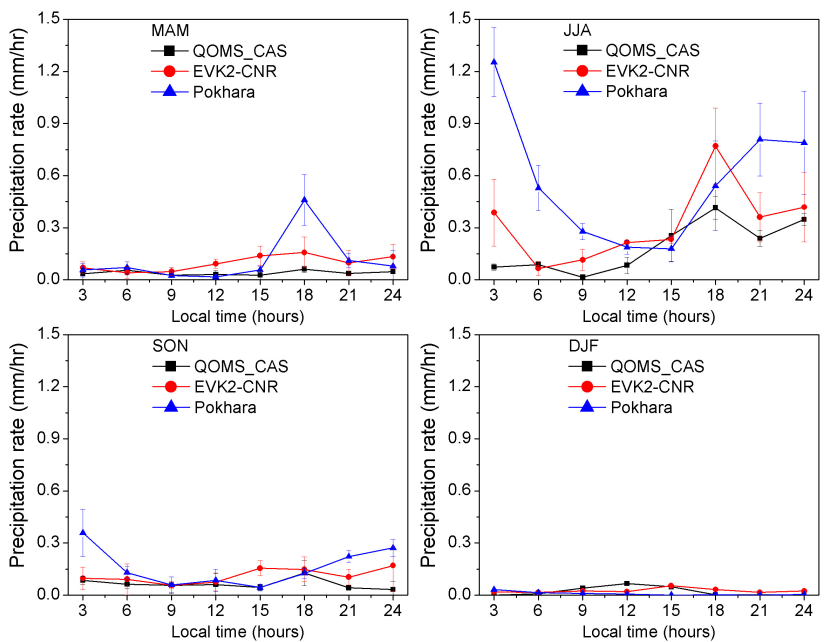

Fig. 8. Diurnal variations of PR at the three stations across all seasons. The error bars indicate the inter-annual difference of PR at each time. MAM denotes March to May, JJA denotes June to August, SON denotes September to November and DJF denotes December to February in the next year (the following season divisions are the same).

$0.46 \mathrm{~mm} \mathrm{~h}^{-1}$ ) occurs at 18:00. No significant rainfall occurs in the rest of the day. In JJA, rainfall decreases before 15:00 and then increases. Lower PR occurs in the early afternoon (12:00 to 15:00). More rainfall occurs in the late afternoon and night. The diurnal variations of PR in SON look like JJA to some extent. However, PR is much lower in SON than in JJA. There is no significant rainfall in winter.

\subsubsection{AOD at $500 \mathrm{~nm}$}

The diurnal variations of AOD at $500 \mathrm{~nm}$ are shown in Fig. 9. Different stations have different diurnal variation patterns. In Fig. 9, QOMS_CAS and Pokhara are shown on the left scale, and EVK2-CNR is shown on the right scale, which make it easier to see the diurnal AOD trends at QOMS_CAS and Pokhara with the lower ranges. At QOMS_CAS, the diurnal variations of $\mathrm{AOD}$ do not have similar patterns among seasons. At EVK2-CNR, AOD increases from morning to sunset across all seasons, and the relative daytime variation ranges are larger than at the other two sites. At Pokhara, AOD decreases from early morning, reaches a minimum at noon, and then increases again significantly in the afternoon, except in summer. The relative daytime variation ranges at Pokhara are close to those at QOMS_CAS. However, the absolute daytime variation ranges of AOD at Pokhara are the largest. The absolute daytime variation ranges of AOD are quite small at QOMS_CAS and EVK2-CNR. Although the absolute daytime variation ranges can be comparable to the uncertainty of AERONET AOD measurements in some seasons, the consistent and repeatable daytime variation pattern by multi-year
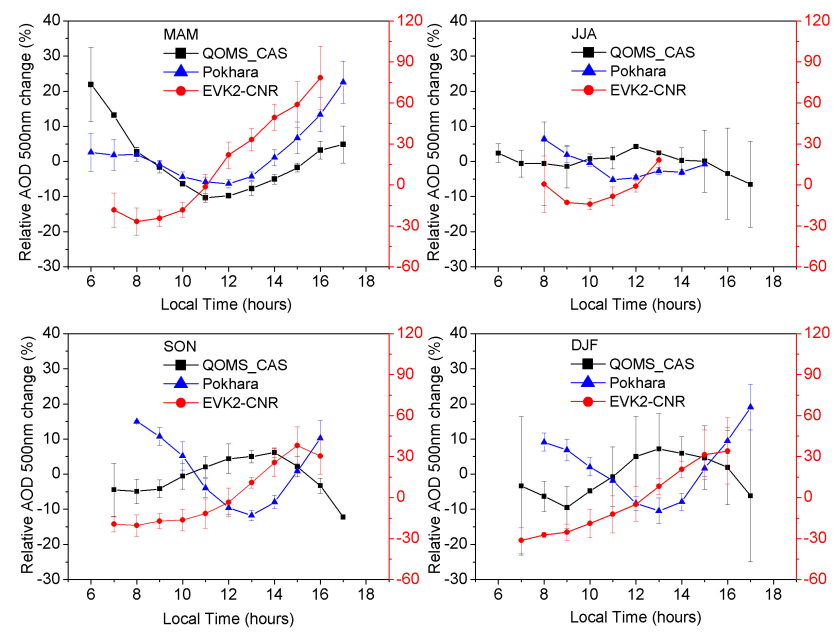

Fig. 9. Percentage deviations of hourly average AOD at $500 \mathrm{~nm}$ relative to their daily mean across all seasons at QOMS_CAS, EVK2CNR and Pokhara. The error bars indicate the inter-annual difference of relative AOD at each hour. The black scale on the left is for QOMS_CAS and Pokhara, while the red scale on the right is for EVK2-CNR.

observations at EVK2-CNR may indicate the physical processes.

At QOMS_CAS, the diurnal variations of AOD do not have similar patterns among seasons. The diurnal cycles have great differences among multiyear observations in each season. In summer (JJA), AOD changes little from morning to 15:00, and then decreases in the late afternoon in each year. This decrease can be associated with rainfall in the late afternoon, deduced from TRMM data. The relative daytime variation range is about $32 \%$ in MAM, $11 \%$ in JJA, $18 \%$ in SON and $18 \%$ in DJF, respectively. Correspondingly, the absolute daytime variation range of AOD is about 0.02 in spring, and it is usually about 0.01 in other seasons.

At EVK2-CNR, the diurnal variations of AOD show similar patterns across all seasons, but with slightly different magnitude. AOD nearly increases from morning to sunset in all seasons. There are fewer available observations in the afternoon in JJA due to heavy precipitation. Because of lacking effective observations in the afternoon, whether or not large rainfall would remove aerosols cannot be deduced in summer. In SON, AOD decreases significantly from 15:00 to 16:00, which may be in accord with TRMM data with higher precipitation from 15:00 to 18:00. The relative daytime variation range is about $105 \%$ in MAM, 32\% in JJA, $59 \%$ in SON and $63 \%$ in DJF, respectively. Correspondingly, the absolute daytime variation range of AOD is about 0.03 in MAM, and about 0.02 in other seasons. The absolute daytime change is related to monthly average AOD.

At Pokhara, the diurnal cycle of AOD has similarities across all seasons and is repeatable between different years (not shown). The diurnal variations of AOD show a similar 

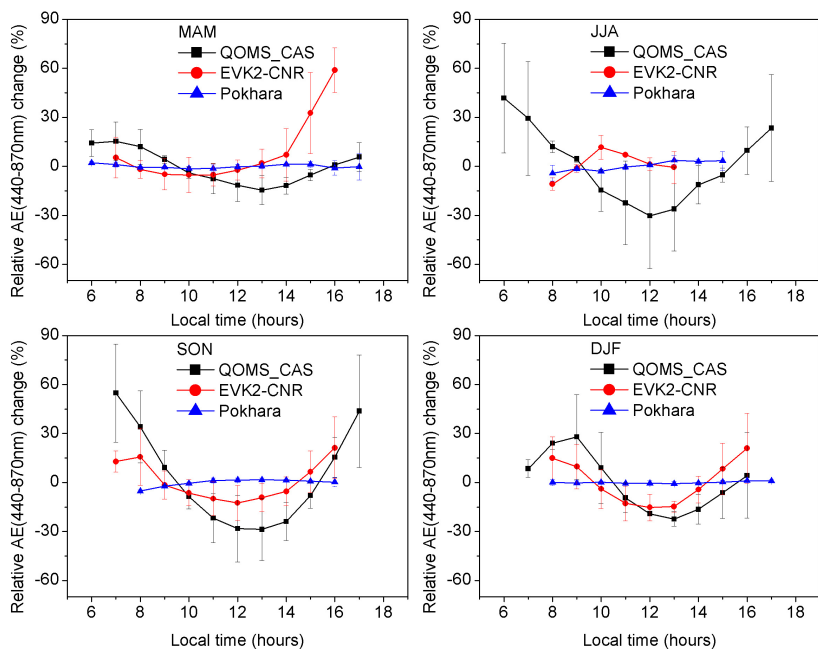

Fig. 10. Percentage deviations of hourly average AE at 440-870 nm relative to their daily mean across all seasons at QOMS_CAS, EVK2-CNR and Pokhara. The error bars indicate the inter-annual difference of relative $\mathrm{AE}$ at each hour.

pattern in spring, autumn and winter. In these three seasons, AOD decreases from early morning, reaches a minimum at 12:00 or 13:00, and then increases significantly. Peak values of AOD occurred at 08:00 in the morning and at 16:00 or 17:00 in the late afternoon, which may be consistent with BC emissions from biofuel cooking at a fixed time (Rehman et al., 2011). The diurnal variations are different in summer as a result of large rainfall. The relative daytime variation range is about $29 \%$ in MAM, $12 \%$ in JJA, $27 \%$ in SON and $30 \%$ in DJF. Correspondingly, the absolute daytime variation range of AOD is about 0.18 in MAM, 0.06 in JJA, 0.09 in SON and 0.10 in DJF.

\subsubsection{AE at $440-870 \mathrm{~nm}$}

The diurnal variations of $\mathrm{AE}$ at $440-870 \mathrm{~nm}$ are shown in Fig. 10. At QOMS_CAS, AE decreases first in the morning and then increases in the afternoon in each season. The relative daytime variation ranges are larger at QOMS_CAS than at the other stations except in spring. The diurnal cycle at EVK2-CNR is similar to that at QOMS_CAS in autumn and winter. At Pokhara, no significant diurnal variations of $\mathrm{AE}$ are found. The relative daytime variation ranges at Pokhara are the smallest. The absolute daytime variation ranges at QOMS_CAS are the largest, and the absolute daytime variation ranges at Pokhara are the smallest.

At QOMS_CAS, the diurnal variations of AE have similar patterns across all seasons. AE drops from the morning, reaches a minimum at noon or in the early afternoon and then increases. The diurnal cycle has similarities among multiyear observations but with slightly different magnitude and phase (not shown). The relative daytime variation range is about $30 \%$ in MAM, $72 \%$ in JJA, $84 \%$ in SON and $50 \%$ in
DJF. Correspondingly, the absolute daytime variation range is $0.29,0.42,0.46$ and 0.37 , respectively. AE is a qualitative indicator, and it can only show the relative particle size. The above results may indicate that relatively larger particles dominate at noon across all seasons.

The diurnal cycle at EVK2-CNR is similar to that at QOMS_CAS in autumn and winter. However, the diurnal variations have great inter-annual differences with different magnitude and phase in spring (not shown). In summer, AE increases from 8:00 to 10:00, and decreases a little from 10:00 to 13:00. No available observations exist in the rest of day. This phenomenon may result from heavy precipitation in the afternoon at EVK2-CNR. In autumn and winter, the daytime variation pattern is quite similar to that at QOMS_CAS. The relative daytime variation range is $64 \%$ in MAM, $23 \%$ in JJA, $34 \%$ in SON and $36 \%$ in DJF. Correspondingly, the absolute daytime variation range is $0.31,0.09,0.18$ and 0.25 , respectively. Therefore, the diurnal variations of AE may indicate relatively larger aerosol size at noon or in the early afternoon in MAM, SON and DJF.

At Pokhara, AE changes little during daytime in each season. The relative daytime variation range is less than $8 \%$ in all seasons. The absolute daytime variation range of $\mathrm{AE}$ is 0.03 in MAM, 0.11 in JJA, 0.11 in SON and 0.03 in DJF. These results indicate the average aerosol particle size hardly changes in each season.

The diurnal variations of $\mathrm{AE}$ can only reflect the relative aerosol size qualitatively, and cannot show the range of particle size exactly. A possible explanation of the larger relative daytime variation ranges at QOMS_CAS and EVK2CNR may be due to greater uncertainties in AE. The calibration error partly resulting from air mass factors in AOD measurement may influence the error for $\mathrm{AE}$ (Wagner and Silva, 2008), when AOD is quite low. Although the large uncertainty of $\mathrm{AE}$ in a region with such low AOD makes the detection of daytime variation difficult, the consistent daytime variation at QOMS_CAS and EVK2-CNR may indicate the presence of relatively larger-size aerosol at noon or in the early afternoon. The direct measurement of aerosol size distribution observations at the Nepal Climate Observatory at Pyramid (collocated with the EVK2-CNR AERONET station) have found that aerosol size grows during late morning and early afternoon, while aerosols in the accumulation mode peak between noon and afternoon in all seasons (Venzac et al., 2008). These direct observation results are in accord with our results.

\subsubsection{Possible factors contributing to aerosol daytime variations}

The diurnal variations of AOD and $\mathrm{AE}$ are due to many factors, including rainfall, emissions, mountain-valley circulations, and surface heating. This section discusses these major factors. 
The diurnal pattern in precipitation appears to contribute significantly to diurnal changes in aerosol properties through the effect of precipitation scavenging. At all three stations more rainfall takes place in the afternoon or in the late afternoon than other times of day. Wet deposition can change the aerosol load. Precipitation may also affect the average particle size. A previous study reported that larger aerosol particles consisting of more internally mixed hygroscopic compounds could be more likely removed via nucleation scavenging (Moteki et al., 2012). Another study proposed that precipitation would tend to remove the larger particles first and then smaller particles after the larger ones have been removed (Tunved et al., 2013). Unfortunately, the effect of precipitation on the average particle size in this study is not confirmed due to the scarcity of available observations when heavy precipitation occurs.

Aerosol properties are also affected by the diurnal emission patterns and the distance between the station and emission sources. The sun photometer at Pokhara is located near Pokhara city, which has significant local urban emission sources. A previous study at Pokhara found that the diurnal mean concentration of $\mathrm{PM}_{10}$ was higher in the morning (07:30 a.m. to 11:30 a.m.) and evening (03:30 p.m. to 07:30 p.m.) than in the afternoon (11:30 a.m. to 03:30 p.m.) (Bashyal et al., 2008). The same pattern was also found in Kathmandu, $145 \mathrm{~km}$ east of Pokhara (Panday and Prinn, 2009). While diurnal patterns of $\mathrm{PM}_{10}$ reflect the emission and ventilation of air pollutants near the ground level, AOD reflects the aerosol loading over the entire column. While it is possible that the morning and evening peaks in $\mathrm{PM}_{10}$ and in AOD coincide because the entire column is heavily influenced by ground level urban air pollution from Pokhara, it is more likely that the column AOD reflects regional emission patterns. Morning and evening meals in many rural households in Nepal, including the ones on the slopes and ridges surrounding Pokhara, are cooked with firewood stoves that are heavy emitters of aerosols. In contrast, QOMS_CAS and EVK2-CNR are both located at high altitudes, far from anthropogenic emission sources, and do not exhibit diurnal patterns related to emissions.

Mountain-valley circulations also influence the transport and deposition of aerosols on a daily timescale. EVK2-CNR is greatly affected by up-valley winds during the daytime. The daytime airflow carries aerosols up from lower-altitude polluted regions, which leads to increasing AOD over the course of the day. The other two stations are located in places that are less influenced by valley winds.

Surface heating has an obvious impact on local convection, which greatly influences the vertical exchange of aerosols between the ABL and free troposphere, and also influences the diffusion rate of pollutants. Previous studies have investigated the vertical distributions of aerosols. At Zhangye station in northwest China, aerosol extinction coefficients in the upper and lower layers decreased with altitude, whereas the coefficient in the middle layer changed slightly, which suggested that aerosol mixing occurred in the middle layer (Zhang et al., 2012a). Sinha et al. (2013) found that aerosols within atmospheric boundary layer (ABL) over a tropical urban station Hyderabad, India dominated the column aerosol loading with ABL-AOD, contributing not less than $50 \%$ throughout the year. Over urban locations in South India, BC mass loadings decreased approximately monotonically from the surface to an altitude of $7 \mathrm{~km}$ (Safai et al., 2012). Atmospheric species concentrated in the ABL are "occasionally transported to the free troposphere in "uplifted plumes' via systematic vertical motions of air" (Moteki et al., 2012). Therefore, the vertical dynamics process of aerosols is related to ABL evolution to some extent. As the sun rises, surface heating increases gradually, reaching a maximum at about 12:00, and then weakens (Ma et al., 2005). Convection in the ABL changes in accord with surface heating (Yanai and $\mathrm{Li}, 1994)$. The convection over the Tibetan Plateau evolves from dry shallow convection in the morning to wet deep convection in the afternoon, while the $\mathrm{ABL}$ reaches its maximum height at 13:00 (LT defined in this study) at QOMS_CAS (Ma et al., 2009). The aerosol parameters measured by the sun photometer reflect the properties of the whole atmosphere. In this discussion, the upper atmosphere represents the atmosphere above ABL, and the lower atmosphere represents the atmospheric conditions within ABL. If aerosols just exchanged between the upper and lower atmosphere, the vertical distribution of aerosols would change, but the aerosol properties would be nearly invariable. If the flow of aerosols into or out of the observation region has changed, the aerosol properties would change accordingly. At QOMS_CAS, AOD does not show a consistent diurnal pattern, while AE has a similar pattern in each season. What are the reasons for this phenomenon? Local aerosols, which dominate in the lower atmosphere, are predominantly composed of natural emissions in the Everest region. Surface wind speed is crucial for picking up coarse mode aerosols from the earth's surface to the atmosphere (Kok, 2011). The surface wind speed always increases greatly in the afternoon (Sun et al., 2007). Aerosols in the lower atmosphere may have a clear daytime variation pattern related to diurnal patterns in emission and in meteorology. Conversely, aerosols in upper atmosphere, such as the free troposphere (FL), mainly consist of aerosols that have been transported long distances. Long-range transport aerosols show random variations on a diurnal timescale. The changes at the lower and upper atmosphere are combined together, which possibly leads to different diurnal variations of AOD among seasons or multiyear observations. Lifted soil particles from the surface usually have relatively large particle size (Lu and Shao, 1999). Intensive convection around noon could transport relatively large particles from natural emissions upwards, which may partly lead to larger column-integrated particle size around noon at QOMS_CAS. In addition, aerosol growth in the atmosphere partly related to solar irradiation leads to the increasing size and mass (Monge et al., 2012), which may 
possibly influence the column-integrated aerosol size. The aerosol load at QOMS_CAS in the upper atmosphere is possibly comparable to that in the lower atmosphere. AOD or AE at QOMS_CAS possibly varies during the daytime as aerosols in the upper and lower atmosphere vary.

The environment at EVK2-CNR is similar to that at QOMS_CAS. Therefore, the diurnal variations of AE in autumn and winter are similar to QOMS_CAS. In the spring, however, the diurnal variations of AE at EVK2-CNR have a different pattern and show great differences among multiyear measurements. On the southern side of the Himalayas, fine and coarse mode particles are mixed to make aerosol composition more complex, which may result in the large inter-annual differences of diurnal curves in spring at EVK2CNR. Surface heating and convection take place in Pokhara too and may explain the observations. At Pokhara, convection transports local pollution upwards in the morning, decreasing concentrations near the surface and increasing pollution in the upper atmosphere. Meanwhile, airflow in or out of the observation region also changes aerosol optical properties, regardless of the vertical distribution. As convection strengthens in the forenoon, diffusion of pollutants into the surrounding rural region increases gradually. This could explain the decrease in AOD at Pokhara in the forenoon. Later in the afternoon AOD in Pokhara increases again. This may be because convection, as well as pollutant diffusion rates, weakens gradually. Xia et al. (2006) and Quan et al. (2013) also found that the diurnal variation was related to the diurnal variation of boundary layer and to associated dilution of aerosols in the troposphere over urban sites. Alternatively, the afternoon increase in AOD in Pokhara may be due to the arrival of regional pollution from the northern Indo-Gangetic Plains by the broader plain-to-plateau circulation.

\section{Conclusions and discussion}

We have investigated seasonal and diurnal aerosol optical properties from three AERONET sites around the Himalayan region. These vary among the three sites at the two timescales. As expected, seasonal changes are profoundly affected by large-scale atmospheric circulation, while diurnal variations are mainly influenced by meso-scale systems and local topography.

Aerosols optical properties exhibit pronounced seasonal variations in the Himalayas. While observations at QOMS_CAS and EVK2-CNR can generally be representative of a remote background atmosphere, observations in Pokhara take place in a suburban site polluted by human activities. Vegetation fires in the Himalayan region and northern India can release large amounts of smoke aerosols, especially in April (Andreae and Merlet, 2001), leading to a growing fine mode aerosol load at QOMS_CAS and EVK2CNR. During monsoon season, dust, wind erosion and hydrated/cloud-processed aerosols may lead to high aerosol loads at QOMS_CAS and EVK2-CNR. The dust concentration may build up in between the rainy days. Coarse mode AOD at EVK2-CNR is higher than at QOMS_CAS in August and September, which indicates that the transport of coarse mode aerosols from the southern to the northern side may be effectively reduced. In and around Pokhara, the atmosphere has been seriously polluted by human activities, leading to much higher aerosol loads than the other two stations. Monthly peak values of total AOD and fine mode AOD are observed in April and October, while lower aerosol loads occur from July to September when heavy rainfall can remove aerosols effectively. The first peak occurs in April in Pokhara for the same reason as the other two sites, while the second peak in October appears to be associated with crop-residue burning.

While Pokhara and EVK2-CNR have similar diurnal variation patterns of AOD across seasons, the diurnal patterns vary at QOMS_CAS. At EVK2-CNR, AOD increases nearly monotonically from morning to sunset across all seasons. At Pokhara, AOD decreases from early morning, reaches a minimum at noon and then increases significantly, except in the summer. The relative daytime variation ranges of AOD at EVK2-CNR are the largest, while the relative daytime variation ranges at QOMS_CAS are comparable to those at Pokhara. The absolute daytime variation ranges of AOD at Pokhara are the largest, and quite small at QOMS_CAS and EVK2-CNR. The absolute daytime variation range of AOD is closely related to the aerosol load at each station. At QOMS_CAS, AE decreases first in the morning and then increases in the afternoon in each season. The daytime variation pattern in autumn and winter at EVK2-CNR is similar to that at QOMS_CAS. But the diurnal cycle of AE is not significant at Pokhara. The relative daytime variation ranges of AE are the largest at QOMS_CAS except in spring, and the smallest at Pokhara.

The diurnal variations of $\mathrm{AOD}$ and $\mathrm{AE}$ are affected by many factors, including rainfall, emission sources, mountain-valley circulations, surface heating and their interactions. Diurnal precipitation leads to the great change of aerosol properties by the effect of precipitation scavenging. Precipitation can reduce the aerosol load. Aerosol properties are also affected by the diurnal emission patterns and the distance between the station and emission sources. Pokhara is near large emission sources, and the enhanced emissions can lead to an increase in AOD in the morning and late afternoon. The other two stations are far from the emission sources so that the aerosol load would not change immediately with the emissions. Mountain-valley circulations also influence daytime aerosol variations. Because valley winds at EVK2-CNR prevail during the daytime in each season, AOD continuously increases. The surface heating has an enormous impact on the local convections, and the convections influence the vertical aerosol exchange as well as the diffusion rate of pollution. The aerosol parameters reflect the aerosol change over the entire column. The aerosol exchange between the upper 
and lower atmosphere can change the vertical distributions of aerosols, but may have no significant influence on aerosol properties. The aerosol properties would change accordingly with the flow of aerosols into or out of the observation region.

The results presented in this study contribute to giving more knowledge on aerosol optical properties between southern and northern sides of the Himalayas. Aerosol daytime variations in the Himalayas are elucidated based on the objective phenomenon of precipitation, wind circulation and source emission variations. For the purpose of improving knowledge about aerosol vertical distribution in the Himalayas, more direct evidence, such as chemical sampling at different atmospheric layers, micro-pulse lidar observations from surface, or lidar remote-sensing measurements have to be used in future studies.

Acknowledgements. This research was funded by the Chinese National Key Programme for Developing Basic Sciences (2010CB951701), the CMA Special Fund for Scientific Research in the Public Interest (GYHY201406001), the Chinese National Natural Science Foundation (91337212, 41275010, 41275028 and 41375009), the EU-FP7 projects of "CORE-CLIMAX"(313085). We would like to thank the editor and three anonymous referees for their very valuable comments greatly improving the paper. We thank G. P. Gobbi (ISACCNR) and G. P. Verza (EVK2-CNR), for their effort in establishing and maintaining the EVK2-CNR AERONET site. The photo at EVK2-CNR showing the surrounding environment is provided by this site. The authors also gratefully acknowledge the efforts made by the AERONET team/site PIs and operators (including at Pokhara and QOMS_CAS). We thank Gupta Giri for his effort in maintaining the Pokhara AERONET site. We would like to acknowledge the NOAA Air Resources Laboratory team for providing the HYSPLIT_4 trajectory model. We also thank ECMWF for providing ERA-interim data and NOAA for providing NCEP/NCAR data. The first author would like to acknowledge J. Qin, Y. Chen, X. Zhang and all the other group members for their help in the procedure of the paper.

Edited by: J. Ma

\section{References}

Anderson, T. L., Charlson, R. J., Winker, D. M., Ogren, J. A., and Holmen, K.: Mesoscale variations of tropospheric aerosols, J. Atmos. Sci., 60, 119-136, doi:10.1175/15200469(2003)060<0119:mvota>2.0.co;2, 2003.

Andreae, M. O. and Merlet, P.: Emission of trace gases and aerosols from biomass burning, Global Biogeochem. Cy., 15, 955-966, doi:10.1029/2000gb001382, 2001.

Ångström, A.: On the atmospheric transmission of sun radiation and on dust in the air, Geogr. Ann., 11, 156-166, 1929.

Ångström, A.: The parameters of atmospheric turbidity, Tellus, 16, 64-75, 1964.

Barros, A. P., Joshi, M., Putkonen, J., and Burbank, D. W.: A study of the 1999 monsoon rainfall in a mountainous region in central Nepal using TRMM products and rain gauge observations,
Geophys. Res. Lett., 27, 3683-3686, doi:10.1029/2000g1011827, 2000.

Bashyal, A., Majumder, A. K., and Khanal, S. N.: Quantification of PM 10 Concentration in Occupation Environment of Traffic Police Personnel in Pokhara Sub-Metropolitan City, Nepal, Kathmandu University, Journal of Science, Engineering and Technology 4, 73-80, doi:10.3126/kuset.v4i1.2886, 2008.

Bonasoni, P., Laj, P., Angelini, F., Arduini, J., Bonafe, U., Calzolari, F., Cristofanelli, P., Decesari, S., Facchini, M. C., Fuzzi, S., Gobbi, G. P., Maione, M., Marinoni, A., Petzold, A., Roccato, F., Roger, J. C., Sellegri, K., Sprenger, M., Venzac, H., Verza, G. P., Villani, P., and Vuillermoz, E.: The ABC-Pyramid Atmospheric Research Observatory in Himalaya for aerosol, ozone and halocarbon measurements, Sci. Total. Environ., 391, 252261, doi:10.1016/j.scitotenv.2007.10.024, 2008.

Bonasoni, P., Laj, P., Marinoni, A., Sprenger, M., Angelini, F., Arduini, J., Bonafè, U., Calzolari, F., Colombo, T., Decesari, S., Di Biagio, C., di Sarra, A. G., Evangelisti, F., Duchi, R., Facchini, MC., Fuzzi, S., Gobbi, G. P., Maione, M., Panday, A., Roccato, F., Sellegri, K., Venzac, H., Verza, GP., Villani, P., Vuillermoz, E., and Cristofanelli, P.: Atmospheric Brown Clouds in the Himalayas: first two years of continuous observations at the Nepal Climate Observatory-Pyramid (5079 m), Atmos. Chem. Phys., 10, 7515-7531, doi:10.5194/acp-10-7515-2010, 2010.

Breon, F. M., Vermeulen, A., and Descloitres, J.: An evaluation of satellite aerosol products against sunphotometer measurements, Remote Sens. Environ., 115, 3102-3111, doi:10.1016/j.rse.2011.06.017, 2011.

Cao, J., Tie, X., Xu, B., Zhao, Z., Zhu, C., Li, G., and Liu, S.: Measuring and modeling black carbon (BC) contamination in the SE Tibetan Plateau, J. Atmos. Chem., 67, 45-60, doi:10.1007/s10874-011-9202-5, 2011.

Carrico, C. M., Bergin, M. H., Shrestha, A. B., Dibb, J. E., Gomes, L., and Harris, J. M.: The importance of carbon and mineral dust to seasonal aerosol properties in the Nepal Himalaya, Atmos. Environ., 37, 2811-2824, doi:10.1016/s1352-2310(03)00197-3, 2003.

Chand, D., Wood, R., Ghan, S. J., Wang, M., Ovchinnikov, M., Rasch, P. J., Miller, S., Schichtel, B., and Moore, T.: Aerosol optical depth increase in partly cloudy conditions, J. Geophys. Res.-Atmos., 117, D17207, doi:10.1029/2012jd017894, 2012.

Chatterjee, A., Adak, A., Singh, A. K., Srivastava, M. K., Ghosh, S. K., Tiwari, S., Devara, P. C., and Raha, S.: Aerosol chemistry over a high altitude station at northeastern Himalayas, India, PloS one, 5, e11122, doi:10.1371/journal.pone.0011122, 2010.

Che, H., Wang, Y., and Sun, J.: Aerosol optical properties at Mt. Waliguan Observatory, China, Atmos. Environ., 45, 6004-6009, doi:10.1016/j.atmosenv.2011.07.050, 2011.

Cong, Z. Y., Kang, S. C., Liu, X. D., and Wang, G. F.: Elemental composition of aerosol in the Nam Co region, Tibetan Plateau, during summer monsoon season, Atmos. Environ., 41, 11801187, doi:10.1016/j.atmosenv.2006.09.046, 2007.

Cong, Z. Y., Kang, S., Smirnov, A., and Holben, B.: Aerosol optical properties at Nam Co, a remote site in central Tibetan Plateau, Atmos. Res., 92, 42-48, doi:10.1016/j.atmosres.2008.08.005, 2009.

Dubovik, O. and King, M. D.: A flexible inversion algorithm for retrieval of aerosol optical properties from Sun and sky radiance 
measurements, J. Geophys. Res.-Atmos., 105, 20673-20696, doi:10.1029/2000jd900282, 2000.

Dubovik, O., Holben, B., Eck, T. F., Smirnov, A., Kaufman, Y. J., King, M. D., Tanre, D., and Slutsker, I.: Variability of absorption and optical properties of key aerosol types observed in worldwide locations, J. Atmos. Sci., 59, 590-608, doi:10.1175/15200469(2002)059<0590:voaaop>2.0.co;2, 2002a.

Dubovik, O., Holben, B. N., Lapyonok, T., Sinyuk, A., Mishchenko, M. I., Yang, P., and Slutsker, I.: Non-spherical aerosol retrieval method employing light scattering by spheroids, Geophys. Res. Lett., 29, 54-1-54-4, doi:10.1029/2001GL014506, 2002 b.

Dumka, U. C., Moorthy, K. K., Tripathi, S. N., Hegde, P., and Sagar, R.: Altitude variation of aerosol properties over the Himalayan range inferred from spatial measurements, J. Atmos. Sol.-Terr. Phy., 73, 1747-1761, doi:10.1016/j.jastp.2011.04.002, 2011.

Eck, T. F., Holben, B. N., Reid, J. S., Dubovik, O., Smirnov, A., O'Neill, N. T., Slutsker, I., and Kinne, S.: Wavelength dependence of the optical depth of biomass burning, urban, and desert dust aerosols, J. Geophys. Res.-Atmos., 104, 3133331349, doi:10.1029/1999jd900923, 1999.

Gautam, R., Hsu, N. C., Lau, K. M., Tsay, S. C., and Kafatos, M.: Enhanced pre-monsoon warming over the Himalayan-Gangetic region from 1979 to 2007, Geophys. Res. Lett., 36, L07704, doi:10.1029/2009GL037641, 2009.

Gautam, R., Hsu, N. C., Tsay, S. C., Lau, K. M., Holben, B., Bell, S., Smirnov, A., Li, C., Hansell, R., Ji, Q., Payra, S., Aryal, D., Kayastha, R., and Kim, K. M.: Accumulation of aerosols over the Indo-Gangetic plains and southern slopes of the Himalayas: distribution, properties and radiative effects during the 2009 pre-monsoon season, Atmos. Chem. Phys., 11, 1284112863, doi:10.5194/acp-11-12841-2011, 2011.

Gobbi, G. P., Kaufman, Y. J., Koren, I., and Eck, T. F.: Classification of aerosol properties derived from AERONET direct sun data, Atmos. Chem. Phys., 7, 453-458, doi:10.5194/acp-7-453-2007, 2007.

Gobbi, G. P., Angelini, F., Bonasoni, P., Verza, G. P., Marinoni, A., and Barnaba, F.: Sunphotometry of the 2006-2007 aerosol optical/radiative properties at the Himalayan Nepal Climate Observatory-Pyramid (5079 m a.s.1.), Atmos. Chem. Phys., 10, 11209-11221, doi:10.5194/acp-10-11209-2010, 2010.

He, Q., Li, C., Tang, X., Li, H., Geng, F., and Wu, Y.: Validation of MODIS derived aerosol optical depth over the Yangtze River Delta in China, Remote Sens. Environ., 114, 1649-1661, doi:10.1016/j.rse.2010.02.015, 2010.

He, Q., Li, C., Geng, F., Lei, Y., and Li, Y.: Study on Longterm Aerosol Distribution over the Land of East China Using MODIS Data, Aerosol Air Qual. Res., 12, 304-319, doi:10.4209/aaqr.2011.11.0200, 2012a.

He, Q., Li, C., Geng, F., Yang, H., Li, P., Li, T., Liu, D., and Pei, Z.: Aerosol optical properties retrieved from Sun photometer measurements over Shanghai, China, J. Geophys. Res.-Atmos., 117, D16204, doi:10.1029/2011JD017220, 2012b.

Holben, B. N., Eck, T. F., Slutsker, I., Tanre, D., Buis, J. P., Setzer, A., Vermote, E., Reagan, J. A., Kaufman, Y. J., Nakajima, T., Lavenu, F., Jankowiak, I., and Smirnov, A.: AERONET - A federated instrument network and data archive for aerosol characterization, Remote Sens. Environ., 66, 1-16, doi:10.1016/s00344257(98)00031-5, 1998.
Holben, B. N., Tanre, D., Smirnov, A., Eck, T. F., Slutsker, I., Abuhassan, N., Newcomb, W. W., Schafer, J. S., Chatenet, B., Lavenu, F., Kaufman, Y. J., Castle, J. V., Setzer, A., Markham, B., Clark, D., Frouin, R., Halthore, R., Karneli, A., O’Neill, N. T., Pietras, C., Pinker, R. T., Voss, K., and Zibordi, G.: An emerging ground-based aerosol climatology: Aerosol optical depth from AERONET, J. Geophys. Res.-Atmos., 106, 12067-12097, doi:10.1029/2001jd900014, 2001.

Huang, J., Minnis, P., Yi, Y., Tang, Q., Wang, X., Hu, Y., Liu, Z., Ayers, K., Trepte, C., and Winker, D.: Summer dust aerosols detected from CALIPSO over the Tibetan Plateau, Geophys. Res. Lett., 34, L18805, doi:10.1029/2007GL029938, 2007.

Huffman, G. J., Adler, R. F., Bolvin, D. T., Gu, G., Nelkin, E. J., Bowman, K. P., Hong, Y., Stocker, E. F., and Wolff, D. B.: The TRMM multisatellite precipitation analysis (TMPA): Quasiglobal, multiyear, combined-sensor precipitation estimates at fine scales, J. Hydrometeorol., 8, 38-55, doi:10.1175/jhm560.1, 2007.

IPCC: Climate Change: The Physical Science Basis, edited by: Solomon, S., Qin, D., Manning, M., Chen, Z., Marquis, M., Avery, K. B., Tignor, M., and Miller, H. L., Cambridge University Press, Cambridge, United Kingdom and New York, NY, USA, 996 pp., 2007.

Kansakar, S. R., Hannah, D. M., Gerrard, J., and Rees, G.: Spatial pattern in the precipitation regime of Nepal, Int. J. Climatol., 24, 1645-1659, doi:10.1002/joc.1098, 2004.

Kato, S., Bergin, M. H., Ackerman, T. P., Charlock, T. P., Clothiaux, E. E., Ferrare, R. A., Halthore, R. N., Laulainen, N., Mace, G. G., Michalsky, J., and Turner, D. D.: A comparison of the aerosol thickness derived from ground-based and airborne measurements, J. Geophys. Res.-Atmos., 105, 1470114717, doi:10.1029/2000JD900013, 2000.

Kaufman, Y. J., Tanre, D., and Boucher, O.: A satellite view of aerosols in the climate system, Nature, 419, 215-223, doi:10.1038/nature01091, 2002.

Kok, J. F.: Does the size distribution of mineral dust aerosols depend on the wind speed at emission?, Atmos. Chem. Phys., 11, 1014910156, doi:10.5194/acp-11-10149-2011, 2011.

Koracin, D., Vellore, R., Lowenthal, D. H., Watson, J. G., Koracin, J., McCord, T., DuBois, D. W., Chen, L. W. A., Kumar, N., Knipping, E. M., Wheeler, N. J. M., Craig, K., and Reid, S.: Regional Source Identification Using Lagrangian Stochastic Particle Dispersion and HYSPLIT Backward-Trajectory Models, J. Air Waste Manage., 61, 660-672, doi:10.3155/10473289.61.6.660, 2011.

Lau, K. M., Kim, M. K., and Kim, K. M.: Asian summer monsoon anomalies induced by aerosol direct forcing: the role of the Tibetan Plateau, Clim. Dynam., 26, 855-864, doi:10.1007/s00382006-0114-z, 2006.

Lee, J., Kim, J., Song, C. H., Kim, S. B., Chun, Y., Sohn, B. J., and Holben, B. N.: Characteristics of aerosol types from AERONET sunphotometer measurements, Atmos. Environ., 44, 3110-3117, doi:10.1016/j.atmosenv.2010.05.035, 2010.

Li, M., Ma, Y., and Zhong, L.: The Turbulence Characteristics of the Atmospheric Surface Layer on the North Slope of Mt. Everest Region in the Spring of 2005, J. Meteorol. Soc. Jpn., 90C, 185193, doi:10.2151/jmsj.2012-C13, 2012.

Li, Z., Chen, H., Cribb, M., Dickerson, R., Holben, B., Li, C., Lu, D., Luo, Y., Maring, H., Shi, G., Tsay, S. C., Wang, P., Wang, 
Y., Xia, X., Zheng, Y., Yuan, T., and Zhao, F.: Preface to special section on East Asian Studies of Tropospheric Aerosols: An International Regional Experiment (EAST-AIRE), J. Geophys. Res.-Atmos., 112, D22S00, doi:10.1029/2007JD008853, 2007.

Li, Z., Li, C., Chen, H., Tsay, S. C., Holben, B., Huang, J., Li, B., Maring, H., Qian, Y., Shi, G., Xia, X., Yin, Y., Zheng, Y., and Zhuang, G.: East Asian Studies of Tropospheric Aerosols and their Impact on Regional Climate (EASTAIRC): An overview, J. Geophys. Res.-Atmos., 116, D00K34, doi:10.1029/2010JD015257, 2011.

Liu, Z., Liu, D., Huang, J., Vaughan, M., Uno, I., Sugimoto, N., Kittaka, C., Trepte, C., Wang, Z., Hostetler, C., and Winker, D.: Airborne dust distributions over the Tibetan Plateau and surrounding areas derived from the first year of CALIPSO lidar observations, Atmos. Chem. Phys., 8, 5045-5060, doi:10.5194/acp-85045-2008, 2008.

Logan, T., Xi, B., Dong, X., Li, Z., and Cribb, M.: Classification and investigation of Asian aerosol absorptive properties, Atmos. Chem. Phys., 13, 2253-2265, doi:10.5194/acp-13-22532013, 2013.

Lu, H. and Shao, Y.: A new model for dust emission by saltation bombardment, J. Geophys. Res.-Atmos., 104, 16827-16842, doi:10.1029/1999JD900169, 1999.

Lu, Z., Streets, D. G., Zhang, Q., and Wang, S.: A novel backtrajectory analysis of the origin of black carbon transported to the Himalayas and Tibetan Plateau during 1996-2010, Geophys. Res. Lett., 39, L01809, doi:10.1029/2011GL049903, 2012.

Ma, Y., Fan, S., Ishikawa, H., Tsukamoto, O., Yao, T., Koike, T., Zuo, H., Hu, Z., and Su, Z.: Diurnal and inter-monthly variation of land surface heat fluxes over the central Tibetan Plateau area, Theor. Appl. Climatol., 80, 259-273, doi:10.1007/s00704-0040104-1, 2005.

Ma, Y., Wang, Y., Wu, R., Hu, Z., Yang, K., Li, M., Ma, W., Zhong, L., Sun, F., Chen, X., Zhu, Z., Wang, S., and Ishikawa, H.: Recent advances on the study of atmosphere-land interaction observations on the Tibetan Plateau, Hydrol. Earth Syst. Sci., 13, 1103-1111, doi:10.5194/hess-13-1103-2009, 2009.

Ma, Y., Wang, Y., Zhong, L., Wu, R., Wang, S., and Li, M.: The Characteristics of Atmospheric Turbulence and Radiation Energy Transfer and the Structure of Atmospheric Boundary Layer over the Northern Slope Area of Himalaya, J. Meteorol. Soc. Jpn., 89A, 345-353, doi:10.2151/jmsj.2011-A24, 2011.

Mishra, A. K. and Shibata, T.: Synergistic analyses of optical and microphysical properties of agricultural crop residue burning aerosols over the Indo-Gangetic Basin (IGB), Atmos. Environ., 57, 205-218, doi:10.1016/j.atmosenv.2012.04.025, 2012.

Monge, M. E., Rosenørn, T., Favez, O., Müller, M., Adler, G., Abo Riziq, A., Rudich, Y., Herrmann, H., George, C., and D' Anna, B.: Alternative pathway for atmospheric particles growth, P. Natl. Acad. Sci. USA, doi:10.1073/pnas.1120593109, 2012.

Moteki, N., Kondo, Y., Oshima, N., Takegawa, N., Koike, M., Kita, K., Matsui, H., and Kajino, M.: Size dependence of wet removal of black carbon aerosols during transport from the boundary layer to the free troposphere, Geophys. Res. Lett., 39, L13802, doi:10.1029/2012GL052034, 2012.

O’Neill, N. T., Eck, T. F., Smirnov, A., Holben, B. N., and Thulasiraman, S.: Spectral discrimination of coarse and fine mode optical depth, J. Geophys. Res.-Atmos., 108, 4559, doi:10.1029/2002JD002975, 2003.
Panday, A. K. and Prinn, R. G.: Diurnal cycle of air pollution in the Kathmandu Valley, Nepal: Observations, J. Geophys. Res.Atmos., 114, D09305, doi:10.1029/2008JD009777, 2009.

Pandithurai, G., Pinker, R. T., Devara, P. C. S., Takamura, T., and Dani, K. K.: Seasonal asymmetry in diurnal variation of aerosol optical characteristics over Pune, western India, J. Geophys. Res.-Atmos., 112, D08208, doi:10.1029/2006JD007803, 2007.

Pant, P., Hegde, P., Dumka, U. C., Sagar, R., Satheesh, S. K., Moorthy, K. K., Saha, A., and Srivastava, M. K.: Aerosol characteristics at a high-altitude location in central Himalayas: Optical properties and radiative forcing, J. Geophys. Res.-Atmos., 111, D17206, doi:10.1029/2005JD006768, 2006.

Quan, J., Gao, Y., Zhang, Q., Tie, X., Cao, J., Han, S., Meng, J., Chen, P., and Zhao, D.: Evolution of planetary boundary layer under different weather conditions, and its impact on aerosol concentrations, Particuology, 11, 34-40, doi:10.1016/j.partic.2012.04.005, 2013.

Ramanathan, V., Crutzen, P. J., Kiehl, J. T., and Rosenfeld, D.: Aerosols, climate, and the hydrological cycle, Science, 294, 2119-2124, doi:10.1126/science.1064034, 2001.

Ramanathan, V. and Ramana, M. V.: Persistent, Widespread, and Strongly Absorbing Haze Over the Himalayan Foothills and the Indo-Gangetic Plains, Pure Appl. Geophys., 162, 1609-1626, doi:10.1007/s00024-005-2685-8, 2005.

Rehman, I. H., Ahmed, T., Praveen, P. S., Kar, A., and Ramanathan, V.: Black carbon emissions from biomass and fossil fuels in rural India, Atmos. Chem. Phys., 11, 7289-7299, doi:10.5194/acp-117289-2011, 2011.

Safai, P. D., Raju, M. P., Maheshkumar, R. S., Kulkarni, J. R., Rao, P. S. P., and Devara, P. C. S.: Vertical profiles of black carbon aerosols over the urban locations in South India, Sci. Total Environ., 431, 323-331, doi:10.1016/j.scitotenv.2012.05.058, 2012.

Sena, E. T., Artaxo, P., and Correia, A. L.: Spatial variability of the direct radiative forcing of biomass burning aerosols and the effects of land use change in Amazonia, Atmos. Chem. Phys., 13, 1261-1275, doi:10.5194/acp-13-1261-2013, 2013.

Singh, R. P., Dey, S., Tripathi, S. N., Tare, V., and Holben, B.: Variability of aerosol parameters over Kanpur, northern India, J. Geophys. Res.-Atmos., 109, D23206, doi:10.1029/2004JD004966, 2004.

Sinha, P. R., Manchanda, R. K., Kaskaoutis, D. G., Kumar, Y. B., and Sreenivasan, S.: Seasonal variation of surface and vertical profile of aerosol properties over a tropical urban station Hyderabad, India, J. Geophys. Res.-Atmos., 118, 749-768, doi:10.1029/2012JD018039, 2013.

Smirnov, A., Holben, B. N., Eck, T. F., Dubovik, O., and Slutsker, I.: Cloud-Screening and Quality Control Algorithms for the AERONET Database, Remote Sens. Environ., 73, 337-349, doi:10.1016/S0034-4257(00)00109-7, 2000.

Smirnov, A., Holben, B. N., Eck, T. F., Slutsker, I., Chatenet, B., and Pinker, R. T.: Diurnal variability of aerosol optical depth observed at AERONET (Aerosol Robotic Network) sites, Geophys. Res. Lett., 29, 2115, doi:10.1029/2002GL016305, 2002a.

Smirnov, A., Holben, B. N., Kaufman, Y. J., Dubovik, O., Eck, T. F., Slutsker, I., Pietras, C., and Halthore, R. N.: Optical properties of atmospheric aerosol in maritime environments, J. Atmos. Sci., 59, 501-523, doi:10.1175/15200469(2002)059<0501:opoaai>2.0.co;2, 2002 b. 
Sun, F., Ma, Y., Li, M., Ma, W., Tian, H., and Metzger, S.: Boundary layer effects above a Himalayan valley near Mount Everest, Geophys. Res. Lett., 34, L08808, doi:10.1029/2007GL029484, 2007.

Tosca, M. G., Randerson, J. T., Zender, C. S., Nelson, D. L., Diner, D. J., and Logan, J. A.: Dynamics of fire plumes and smoke clouds associated with peat and deforestation fires in Indonesia, J. Geophys. Res.-Atmos., 116, D08207, doi:10.1029/2010JD015148, 2011.

Tunved, P., Ström, J., and Krejci, R.: Arctic aerosol life cycle: linking aerosol size distributions observed between 2000 and 2010 with air mass transport and precipitation at Zeppelin station, Ny-Ålesund, Svalbard, Atmos. Chem. Phys., 13, 3643-3660, doi:10.5194/acp-13-3643-2013, 2013.

Vadrevu, K. P., Badarinath, K. V., and Anuradha, E.: Spatial patterns in vegetation fires in the Indian region, Environ. Monit. Assess., 147, 1-13, doi:10.1007/s10661-007-0092-6, 2008.

Vadrevu, K. P., Ellicott, E., Giglio, L., Badarinath, K. V. S., Vermote, E., Justice, C., and Lau, W. K. M.: Vegetation fires in the himalayan region - Aerosol load, black carbon emissions and smoke plume heights, Atmos. Environ., 47, 241-251, doi:10.1016/j.atmosenv.2011.11.009, 2012.

Venzac, H., Sellegri, K., Laj, P., Villani, P., Bonasoni, P., Marinoni, A., Cristofanelli, P., Calzolari, F., Fuzzi, S., Decesari, S., Facchini, M. C., Vuillermoz, E., and Verza, G. P.: High frequency new particle formation in the Himalayas, P. Natl. Acad. Sci. USA, 105, 15666-15671, doi:10.1073/pnas.0801355105, 2008.

Wagner, F. and Silva, A. M.: Some considerations about Ångström exponent distributions, Atmos. Chem. Phys., 8, 481-489, doi:10.5194/acp-8-481-2008, 2008.

Wang, J., Xia, X., Wang, P., and Christopher, S. A.: Diurnal variability of dust aerosol optical thickness and Ångström exponent over dust source regions in China, Geophys. Res. Lett., 31, L08107, doi:10.1029/2004GL019580, 2004.

Wang, L., Xin, J., Wang, Y., Li, Z., Liu, G., and Li, J.: Evaluation of the MODIS aerosol optical depth retrieval over different ecosystems in China during EAST-AIRE, Atmos. Environ., 41, 71387149, doi:10.1016/j.atmosenv.2007.05.001, 2007.

Wild, M.: Global dimming and brightening: A review, J. Geophys. Res.-Atmos., 114, D00D16, doi:10.1029/2008jd011470, 2009.

Wu, G., Liu, Y., Wang, T., Wan, R., Liu, X., Li, W., Wang, Z., Zhang, Q., Duan, A., and Liang, X.: The influence of mechanical and thermal forcing by the Tibetan Plateau on Asian climate, J. Hydrometeorol., 8, 770-789, doi:10.1175/jhm609.1, 2007.
Wu, G., Liu, Y., He, B., Bao, Q., Duan, A., and Jin, F.-F.: Thermal controls on the Asian summer monsoon, Scientific Reports, 2, 404, doi:10.1038/srep00404, 2012.

Xia, X. A., Chen, H. B., Wang, P. C., Zhang, W. X., Goloub, P., Chatenet, B., Eck, T. F., and Holben, B. N.: Variation of columnintegrated aerosol properties in a Chinese urban region, J. Geophys. Res.-Atmos., 111, D05204, doi:10.1029/2005JD006203, 2006.

Xia, X. G., Wang, P. C., Wang, Y. S., Li, Z. Q., Xin, J. Y., Liu, J., and Chen, H. B.: Aerosol optical depth over the Tibetan Plateau and its relation to aerosols over the Taklimakan Desert, Geophys. Res. Lett., 35, L16804, doi:10.1029/2008g1034981, 2008.

Xia, X. G., Zong, X. M., Cong, Z. Y., Chen, H. B., Kang, S. C., and Wang, P. C.: Baseline continental aerosol over the central Tibetan plateau and a case study of aerosol transport from South Asia, Atmos. Environ., 45, 7370-7378, 2011.

Xu, B., Cao, J., Hansen, J., Yao, T., Joswia, D. R., Wang, N., Wu, G., Wang, M., Zhao, H., Yang, W., Liu, X., and He, J.: Black soot and the survival of Tibetan glaciers, P. Natl. Acad. Sci. USA, 106, 22114-22118, doi:10.1073/pnas.0910444106, 2009.

Yanai, M., and Li, C. F.: Mechanism of heating and the boundarylayer over the Tibetan Plateau, Mon. Weather Rev., 122, 305323, doi10.1175/1520-0493(1994)122<0305:mohatb>2.0.co;2, 1994.

Yang, K., Ye, B., Zhou, D., Wu, B., Foken, T., Qin, J., and Zhou, Z.: Response of hydrological cycle to recent climate changes in the Tibetan Plateau, Clim. Change, 109, 517-534, doi:10.1007/s10584-011-0099-4, 2011.

Yao, T., Thompson, L., Yang, W., Yu, W., Gao, Y., Guo, X., Yang, X., Duan, K., Zhao, H., Xu, B., Pu, J., Lu, A., Xiang, Y., Kattel, D. B., and Joswiak, D.: Different glacier status with atmospheric circulations in Tibetan Plateau and surroundings, Nature Climate Change, 2, 663-667, doi:10.1038/nclimate1580, 2012.

Zhang, J., Zhang, Q., Tang, C., and Han, Y.: Aerosol structure and vertical distribution in a multi-source dust region, J. Environ. Sci., 24, 1466-1475, doi:10.1016/S1001-0742(11)60919-4, 2012a.

Zhang, Y., Yu, H. B., Eck, T. F., Smirnov, A., Chin, M., Remer, L. A., Bian, H. S., Tan, Q., Levy, R., Holben, B. N., and Piazzolla, S.: Aerosol daytime variations over North and South America derived from multiyear AERONET measurements, J. Geophys. Res.-Atmos., 117, D05211, doi:10.1029/2011JD017242, 2012 b. 